\title{
IL-7 enhances peripheral $T$ cell reconstitution after allogeneic hematopoietic stem cell transplantation
}

\author{
Önder Alpdogan, Stephanie J. Muriglan, Jeffrey M. Eng, Lucy M. Willis, \\ Andrew S. Greenberg, Barry J. Kappel, and Marcel R.M. van den Brink \\ Department of Medicine, Memorial Sloan-Kettering Cancer Center, New York, New York, USA
}

\begin{abstract}
We used clinically relevant murine allogeneic bone marrow transplantation (BMT) models to study the mechanisms by which IL-7 administration can improve posttransplant peripheral $\mathrm{T}$ cell reconstitution. After transplant we could distinguish two populations of mature donor T cells: (a) alloreactive T cells with decreased expression of CD127 (IL-7 receptor $\alpha$ chain) and (b) nonalloreactive T cells, which express CD127 and undergo homeostatic proliferation. IL-7 administration increased the homeostatic proliferation of nonalloreactive $T$ cells, but had no effect on alloreactive $T$ cells and the development of graft-versus-host disease. Allogeneic transplant of purified hematopoietic stem cells and adoptive transfer of thymocytes into lethally irradiated hosts suggested that recent thymic emigrants can undergo homeostatic proliferation and acquire a memory-like phenotype. We found by BrdU pulse-chase, cell cycle, and annexin $V$ analyses that IL-7 administration has significant proliferative and antiapoptotic effects on posttransplant peripheral $T$ cells. We conclude that homeostatic expansion is important for $\mathrm{T}$ cell reconstitution after allogeneic BMT and involves both transferred mature $\mathrm{T}$ cells and recent thymic emigrants. Apart from its thymopoietic effects, IL-7 promotes peripheral T cell reconstitution through its selective proliferative and antiapoptotic effects on nonalloreactive and de novo-generated $\mathrm{T}$ cells, but has no effect on alloreactive $\mathrm{T}$ cells.
\end{abstract}

J. Clin. Invest. 112:1095-1107 (2003). doi:10.1172/JCI200317865.

\begin{abstract}
Introduction
Recipients of allogeneic hematopoietic stem cell transplantation (HSCT) suffer from a prolonged posttransplant immune deficiency that results in significant morbidity and mortality from infections (1-3). This immune deficiency is most pronounced in the $\mathrm{T}$ cell lineage due to a severe delay in $\mathrm{T}$ cell reconstitution. Reconstitution of $\mathrm{CD}^{+} \mathrm{T}$ cells in particular is severely impaired in adult recipients, and the rate of recovery of $\mathrm{CD}^{+} \mathrm{T}$ cells is inversely related to the age of the recipient and correlates with the risk of developing infections (3-5). Posttransplant $\mathrm{T}$ cell recovery is affected by a number of factors, including previous chemo/radiation therapy, a lack of sustained transfer of donor immunity, recapitulation of immunological ontology, age of the recipient, infections, thymic involution after puberty, donor/host histoincompatibility, graft-versushost disease (GVHD), graft rejection, and drug-induced
\end{abstract}

Received for publication January 15, 2003, and accepted in revised form August 5, 2003.

Address correspondence to: Marcel R.M. van den Brink, Memorial Sloan-Kettering Cancer Center, Kettering 406D, Mailbox 111, 1275 York Avenue, New York, New York 10021, USA. Phone: (212) 639-5606; Fax: (917) 432-2375;

E-mail: vandenbm@mskcc.org.

Conflict of interest: The authors have declared that no conflict of interest exists.

Nonstandard abbreviations used: hematopoietic stem cell transplantation (HSCT); graft-versus-host disease (GVHD); $\mathrm{T}$ cell receptor (TCR); bone marrow (BM); BM transplantation (BMT); phycoerythrin (PE); T cell depleted (TCD); 7-aminoactinomycin D (7-AAD); recent thymic emigrant (RTE); mixed lymphocyte reaction (MLR). immunosuppression such as from antibiotics or GVHD prophylaxis (reviewed in ref. 6).

Prolonged T cell deficiency after transplant continues even after quantitative regeneration has taken place, suggesting that a $T$ cell dysfunction occurs in the posttransplant period that is still poorly understood (7-10). This impaired T cell immunity is at least partially explained by the limited diversity of the posttransplant $\mathrm{T}$ cell receptor (TCR) repertoire (11).

Posttransplant $\mathrm{T}$ cell reconstitution involves thymusdependent de novo $\mathrm{T}$ cell generation, extrathymic expansion of mature $T$ cells that were transferred with the allograft, and possibly de novo $\mathrm{T}$ cell generation from extrathymic sites such as mucosa-associated lymphoid tissues in the gut (12). Previous studies in mice and humans have suggested that $\mathrm{T}$ cell reconstitution in older recipients is more dependent on extrathymic expansion of mature $T$ cells than on thymopoiesis; this conclusion was based upon the delayed reappearance of naive $\mathrm{T}$ cells (especially CD4 ${ }^{+} \mathrm{T}$ cells) and a diminished $\mathrm{T}$ cell repertoire $(13-18)$.

The size of the peripheral $\mathrm{T}$ cell pool can rapidly expand and contract during an antigen-specific immune response, but remains remarkably constant throughout life due to tight regulation by a number of cytokines (especially IL-7 and IL-15), and in the case of naive T cells, the interaction of the TCR with self-peptide-MHC ligands (reviewed in ref. 19). Homeostatic expansion/proliferation is an important regulatory mechanism of $\mathrm{T}$ cell homeostasis and is defined as the proliferative response of mature $T$ cells in a lymphopenic environment. Naive T cells convert 
to a memory-like phenotype and require IL-7 and TCR recognition during homeostatic proliferation.

IL-7 is a $\gamma$-common chain cytokine, which is secreted by stromal cells in bone marrow (BM) and thymus and plays an important role in the development, survival, and homeostatic proliferation of T cells (19-22).

In this study, we examined the contribution of homeostatic proliferation, which is associated with the acquisition of a memory-like phenotype, to $\mathrm{T}$ cell reconstitution in recipients of allogeneic HSCT. Our data suggest that in addition to mature $T$ cells (transferred in the allograft), de novo-generated $\mathrm{T}$ cells (derived from donor hematopoietic precursor cells) also undergo homeostatic proliferation in the lymphopenic posttransplant environment of the recipient. We found that posttransplant IL-7 administration promotes $T$ cell reconstitution not only through its effects on thymopoiesis (as we have previously shown, as described in ref. 23), but also by stimulating homeostatic proliferation of nonalloreactive donor $\mathrm{T}$ cells (either de novo-generated or transferred with the allograft) and antiapoptotic effects on peripheral T cells.

\section{Methods}

Mice and BM transplantation. Female C57BL/6 $\left(\mathrm{B} 6, \mathrm{H}-2^{\mathrm{b}}\right)$, C3FeB6F1 (H-2 $\left.2^{\mathrm{b} / \mathrm{k}}\right), \mathrm{B} 6 \mathrm{D} 2 \mathrm{~F} 1 / \mathrm{J}\left(\mathrm{H}-2^{\mathrm{b} / \mathrm{d}}\right)$, B10.BR $\left(\mathrm{H}-2^{\mathrm{k}}\right)$, $\mathrm{CBA} / \mathrm{J}\left(\mathrm{H}-2^{\mathrm{k}}\right)$, and $\mathrm{C} 57 \mathrm{BL} / 6\left(\mathrm{Ly} 5.1^{+}\right)$mice were obtained from The Jackson Laboratory (Bar Harbor, Maine, USA). For some experiments, C57BL/6 (Ly5.1 $1^{+}$mice were obtained from the National Cancer Institute (Frederick, Maryland, USA). Mice used in BM transplantation (BMT) experiments were between 8 weeks and 10 weeks of age or were 9 months (CBA/J) of age. BMT protocols were approved by the Memorial Sloan-Kettering Cancer Center Institutional Animal Care and Use Committee. BM cells were removed aseptically from femurs and tibias. Donor BM was T cell depleted (TCD) by incubation with anti-Thy-1.2 for 30 minutes at $4^{\circ} \mathrm{C}$, followed by incubation with Low-TOX-M rabbit complement (Cedarlane Laboratories Ltd., Hornby, Ontario, Canada) for 40 minutes at $37^{\circ} \mathrm{C}$. Splenic T cells were obtained either by purification over a nylon wool column, by positive selection with anti-CD5 antibodies conjugated to magnetic beads (Miltenyi Biotec, Auburn, California, USA), or by negative selection using lineagespecific antibodies (NK1.1, Gr-1, Mac-1, B220) conjugated to FITC or phycoerythrin (PE) followed by antiFITC or anti-PE antibodies coupled to magnetic beads (Miltenyi Biotec). Cells $\left(5 \times 10^{6}\right.$ to $10 \times 10^{6} \mathrm{BM}$ cells with or without splenic $T$ cells) were resuspended in DMEM (Life Technologies, Grand Island, New York, USA) and transplanted by tail vein infusion ( $0.25 \mathrm{ml}$ total volume) into lethally irradiated recipients on day 0 . On day 0 , prior to transplantation, recipients received $1,300 \mathrm{cGy}$ total body irradiation $\left({ }^{137} \mathrm{Cs}\right.$ source) as a split dose with a 3-hour interval between doses (to reduce gastrointestinal toxicity). Mice were housed in sterilized microisolator cages and received normal chow and autoclaved hyperchlorinated drinking water ( $\mathrm{pH}$ 3.0).
Reagents and antibodies. Anti-murine CD16/CD32 FcR block (2.4G2) and all of the following fluorochromelabeled antibodies against murine antigens were obtained from BD PharMingen (San Diego, California, USA): Ly9.1 (30C7), CD3 (145-2C11), CD4 (RM4-5), CD8 (53-6.7), CD62L (MEL-14), CD122 (TM-B1), CD44 (IM7), CD45R/B220 (RA3-6B2), NK1.1 (PK136), CD11b (M1/70), CD25 (PC61), CD127 (B12-1), CD69 (H1.2F3), c-kit (2B8), SCA-1 (D7), Bcl-2 (3F11), annexin $\mathrm{V}$, the BrdU detection kit, 7-amino-actinomycin $\mathrm{D}$ (7-AAD), isotypic controls, rat IgG2a, $\mathrm{K}$ (R35-95), rat IgG2a, $\lambda$ (B39-4), rat IgG2b, א (A95-1), rat IgG1, $(\mathrm{R} 3-34)$, hamster IgG1, א (A19-3), and hamster IgG2, $\lambda$ (Ha4/8). Streptavidin-FITC, -PE, and -peridinin chlorophyll protein were also obtained from BD PharMingen. Recombinant human IL-7 was kindly provided by Michel Morre (Cytheris, Vanves, France). CFSE was obtained from Molecular Probes Inc. (Eugene, Oregon, USA). BrdU (Sigma-Aldrich, St. Louis, Missouri, USA) and deoxyribonuclease I (DN-25; Sigma-Aldrich) were used in BrdU and cell cycling studies.

Tissue culture medium consisted of RPMI 1640 supplemented with $10 \%$ heat-inactivated FCS, $100 \mathrm{U} / \mathrm{ml}$ penicillin, $100 \mu \mathrm{g} / \mathrm{ml}$ streptomycin, and $2 \mathrm{mM}$ L-glutamine.

Administration of BrdU. Recipients of allogeneic BMT received $\mathrm{BrdU}(0.8 \mathrm{mg} / \mathrm{ml})$ from day 15 to day 33 after transplant in their drinking water, which was prepared fresh daily and protected from light.

Administration of IL-7. For immune reconstitution studies, IL-7 was given from day 21 to day 27 (10 $\mu \mathrm{g}$ /day intraperitoneally). For GVHD studies, IL-7 was administered on days 0-7 (10 $\mu \mathrm{g} /$ day intraperitoneally). In adoptive transfer experiments with CFSE-labeled T cells, IL-7 was administered at a dose of $10 \mu \mathrm{g} /$ day intraperitoneally from day 0 to day 3 .

Purified stem cell preparation. BM cells from donor mice were obtained as described above. Lineage-negative cells were obtained by magnetic bead cell separation using lineage-specific antibodies against CD3, NK1.1, Gr-1, Mac-1, B220, CD4, and CD8. These lineage-negative cells were incubated with antibodies against SCA- 1 and c-kit, and then lineage-negative SCA- $1^{+}$and c-kit ${ }^{+}$cells were obtained by flow cytometric-assisted cell sorting (MoFlo; Cytomation Inc., Fort Collins, Colorado, USA) as previously described (24).

Assessment of GVHD. The severity of GVHD was assessed with a clinical GVHD scoring system as previously described (25). Briefly, ear-tagged animals in coded cages were individually scored every week for five clinical parameters on a scale from 0 to 2: weight loss, posture, activity, fur, and skin. A clinical GVHD index was generated by summation of the five criteria scores to give a total score of $0-10$. Survival was monitored daily. Animals with scores of 5 or higher were considered moribund and were sacrificed.

Cells. As described before, splenic T cells were obtained by purification over a nylon wool column, which resulted in greater than $70 \%$ purity. Single-cell suspensions were prepared from inguinal and axillary lymph nodes and 
spleens according to standard protocols and used for flow cytometric analysis. Intraepithelial lymphocytes from gut were obtained as published previously (26). Briefly, mesenteric tissues were removed from intestines that were then cut longitudinally, washed with PBS, and put into 250-ml cell culture flasks. Segments of intestines were incubated with RPMI with $10 \% \mathrm{FCS}$ for 1 hour at $37^{\circ} \mathrm{C}$ in a shaker. Finally, cells released from the intestine into the medium were obtained using either a nylon wool column or Percoll gradient separation. Single-cell suspensions of liver cells were obtained by Percoll gradient separation.

CFSE labeling. Cells were labeled with CFSE as described previously (27). Briefly, cells (thymocytes or splenocytes) were incubated with CFSE at a final concentration of $2.5 \mu \mathrm{M}$ in $\mathrm{HBSS}$ at $37^{\circ} \mathrm{C}$ for 10 minutes. Cells were then washed three times with HBSS before intravenous injection.

Flow cytometric analysis. Cells were washed in FACS buffer (PBS with $0.5 \%$ BSA and $0.1 \%$ sodium azide), and $10^{6}$ cells $/ \mathrm{ml}$ were incubated for 30 minutes at $4{ }^{\circ} \mathrm{C}$ with CD16/CD32 FcR block. Subsequently, cells were incubated for 30 minutes at $4^{\circ} \mathrm{C}$ with antibodies and washed twice with FACS buffer. The stained cells were resuspended in FACS buffer and analyzed on a FACScan flow cytometer (Becton, Dickinson and Co., San Jose, California, USA) with CellQuest software or with FlowJo software (Tree Star Inc., San Carlos, California, USA).

Intracellular staining. Cells were incubated for 5 hours with $10 \mathrm{ng} / \mathrm{ml}$ PMA and $2 \mu \mathrm{M}$ ionomycin. Brefeldin A $(10 \mu \mathrm{g} / \mathrm{ml})$ was added after 2 hours of incubation. The cells were then harvested, washed, and stained with fluorochrome-conjugated antibodies against cell surface antigens. Subsequently, cells were fixed and permeabilized with Cytofix/Cytoperm Kit reagents (BD PharMingen) and stained with PE-conjugated antibodies.

$B r d U$ and 7-AAD staining for cell proliferation. Single-cell suspensions of spleens were obtained from allogeneic BMT recipients at day 28 or day 33. Cells were stained with fluorochrome-conjugated antibodies against cell surface antigens. The cells were then washed, fixed, permeabilized, and refixed according to manufacturer protocol using the BrdU Flow Kit (BD PharMingen). Fixed cells were incubated with DNase for 1 hour at $37^{\circ} \mathrm{C}$ and then washed and stained with anti-BrdU antibody or 7-AAD. Finally, flow cytometric analysis was conducted by gating for the designated populations and the FL3 fluorescence detector was used in linear mode for 7-AAD analysis.

Proliferation assay. Splenocytes $\left(5 \times 10^{4}\right.$ cells/well; prepared as described above) were incubated for 5 days with irradiated (2,000 cGy) C3FeB6F1 splenocytes as stimulators $\left(2 \times 10^{5}\right.$ cells/well $)$ in 96-well plates. Cultures were pulsed during the final 18 hours with 1 microcurie/well ${ }^{3} \mathrm{H}$-thymidine and cells were harvested with a Topcount Harvester (Packard Bioscience Co., Meriden, Connecticut, USA).

Statistics. All values are expressed as mean \pm SEM. Statistical comparison of experimental data was performed with the nonparametric unpaired MannWhitney $U$ test, whereas the Mantel-Cox log rank test was used for survival data. A $P$ value below 0.05 was considered statistically significant.

\section{Results}

T cell reconstitution is delayed after allogeneic BMT. To study peripheral $T$ cell reconstitution after allogeneic HSCT and the effects of IL-7, we used well-described clinically relevant $\mathrm{MHC}$-matched and -mismatched murine allogeneic BMT models. First, we analyzed the donorderived immune reconstitution after a TCD allogeneic BMT (in which case no GVHD occurs) or an allogeneic BMT with GVHD in an MHC-matched model with a disparity in minor histocompatibility antigens: B10.BR $\rightarrow \mathrm{CBA} / \mathrm{J}(23,28,29)$. GVHD was induced by the addition of donor splenic $\mathrm{T}$ cells to the allograft. We chose this model because of its clinical relevance for and resemblance to patients receiving an allogeneic HSCT from an MHC-matched unrelated donor. These patients suffer from a profound and prolonged posttransplant immune deficiency associated with high mortality from infections, which is in most studies even higher than mortality from relapse (2, 30-34).

Donor-derived $\mathrm{T}$ cell reconstitution was severely delayed, and even at 3 months after BMT the numbers of $\mathrm{CD}^{+}, \mathrm{CD}^{+}$, and $\mathrm{CD}^{+} \mathrm{T}$ cells had not reached the levels found in normal host or donor mice (Figure 1a). Similar to $\mathrm{T}$ cell reconstitution in allogeneic HSCT patients (3), early $\mathrm{CD}^{+} \mathrm{T}$ cell reconstitution was slower than $\mathrm{CD}^{+} \mathrm{T}$ cell reconstitution, and the $\mathrm{CD} 4 / \mathrm{CD} 8$ ratio was decreased during the first 6 weeks after transplant (data not shown). Donor-derived $T$ cell reconstitution in recipients with GVHD remained severely suppressed until the mice died; this is reminiscent of the severe immunosuppression found in patients with GVHD (35).

In contrast to the severely suppressed B cell reconstitution in recipients with GVHD, the numbers of donorderived $\mathrm{B}$ cells in allogeneic TCD-BMT recipients reached the levels of those in nontransplanted host animals by 6 weeks after transplant (Figure 1b). Numbers

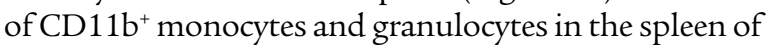
allogeneic TCD-BMT recipients were three- to fourfold higher than in normal donor and host animals in the first 2 weeks after transplant, and normalized by 6 weeks after transplant (data not shown). This early increase in $\mathrm{CD}_{11} \mathrm{~b}^{+}$cells is probably be due to granulopoiesis in the spleen during the first weeks after transplant. Interestingly, recipients with GVHD also had high numbers of CD $11 b^{+}$cells, which had not decreased by 6 weeks after transplant when all animals had died from GVHD. Finally, NK reconstitution was rapid, and numbers of donor-derived NK cells reached the levels of normal donor and host animals by 4 weeks (data not shown).

Posttransplant administration of IL-7 increases donor-derived memory-like CD44 high $T$ cells. In addition to the profound delay in $\mathrm{T}$ cell reconstitution, we noted that most donorderived $\mathrm{CD}^{+}$and $\mathrm{CD}^{+} \mathrm{T}$ cells had a memory-like CD44high phenotype at day 28 after an allogeneic TCDBMT (Figure 1c). In our previously published experiments, we did not observe any difference in $T$ cell recovery 
in the thymus or periphery between IL-7-treated and control groups when IL-7 was administered from day 0 to day 14 after BMT (23). However, we found increased immune reconstitution after IL-7 administration from day 14 to day 28 (continuous by subcutaneous pump) or from day 21 to day 27 (intraperitoneally). Therefore, we treated recipients from day 21 to day 28 after BMT with IL-7. Because IL-7 administration could stimulate early lymphoid precursors, which can express IL-7R (36) and need 15-18 days to differentiate into naive $T$ cells (37), we measured donor-derived naive and memory $\mathrm{T}$ cell populations at varying times after transplant. This also allowed us to assess the duration of the IL-7-induced increase in T cell numbers after discontinuation of IL-7 administration. We detected no increase in naive $\mathrm{CD}^{+}$ $\mathrm{T}$ cells and only a small (but significant) increase in naive
$\mathrm{CD}^{+} \mathrm{T}$ cells at day 28 after transplant (Figure $1 \mathrm{~d}$ ). In contrast, memory-like $\mathrm{CD}^{+}$and $\mathrm{CD}^{+} \mathrm{T}$ cells in IL-7treated recipients were significantly increased, and donor-derived memory-like $\mathrm{CD} 4^{+} \mathrm{T}$ cells on day 28 reached even higher levels than in normal animals.

Nonalloreactive donor T cells undergo bomeostatic proliferation upon transfer to lethally irradiated allogeneic recipients. To better understand the preferential effect of IL-7 on the posttransplant reconstitution of memory/activated $\mathrm{T}$ cells, we first analyzed the phenotype and proliferation of the various populations of donor $T$ cells after allogeneic BMT, including (a) alloreactive $\mathrm{T}$ cells, mature $T$ cells contained in the allograft that recognize host allo-antigens and cause GVHD; (b) nonalloreactive $\mathrm{T}$ cells, mature $\mathrm{T}$ cells in the allograft that do not recognize alloantigens but have been suggested to con-
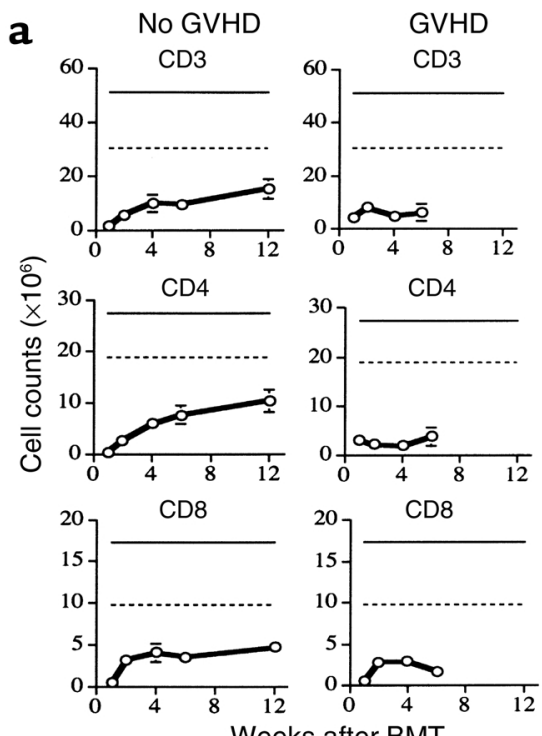

Weeks after BMT
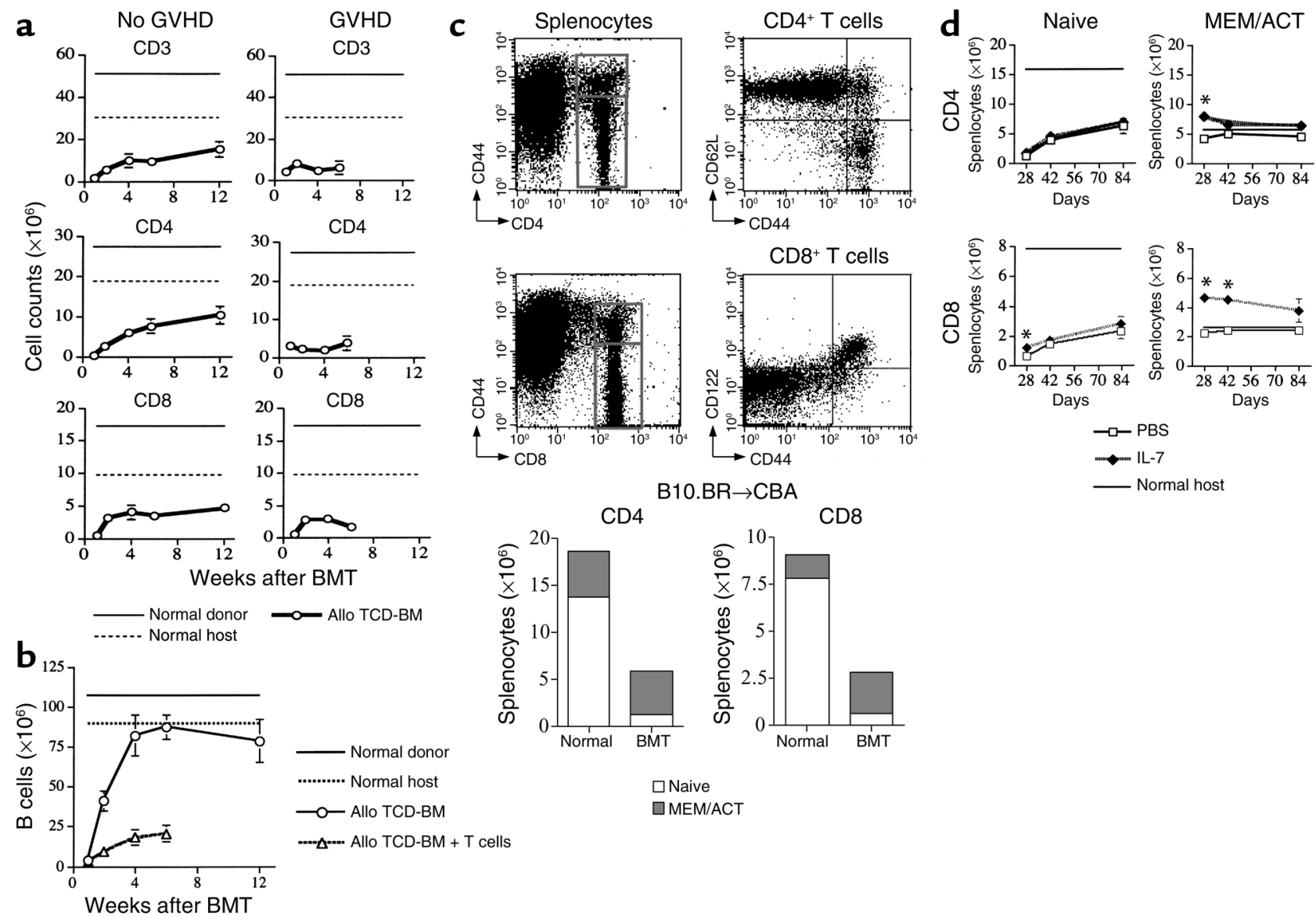

$\rightarrow-$ PBS
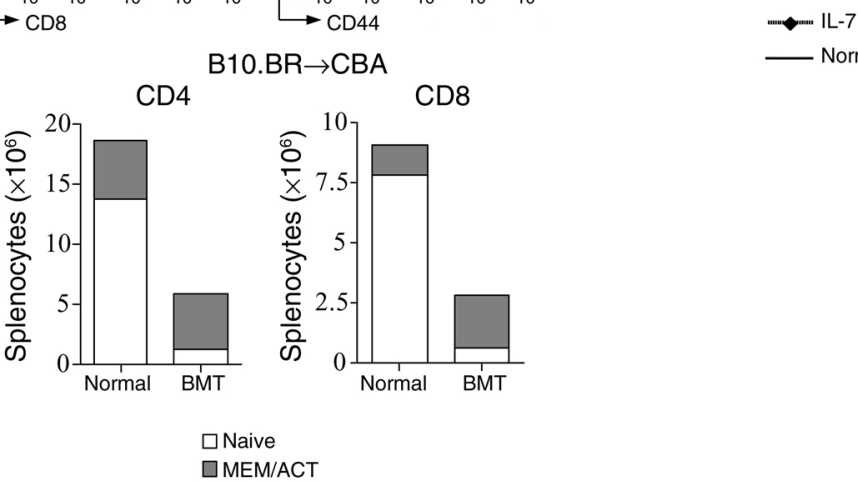

Normal host

\section{Figure 1}

T cell and B cell reconstitution after allogeneic BMT. (a and b) Lethally irradiated (1,300 cGy) CBA/J recipients were transplanted with B10.BR TCD-BM $\left(5 \times 10^{6}\right)$ with or without B10.BR T cells $\left(0.5 \times 10^{6}\right)$ to induce GVHD. At different timepoints after BMT, animals were sacrificed and absolute numbers of donor-derived cell populations in the spleen were calculated from total cell counts and multicolor flow cytometric analyses of T cells with anti-CD3,-CD4, and -CD8 antibodies (a), and B cells with anti-B220 antibody (b). Donor or host origin was determined with anti-Ly9.1, which is present on host leukocytes. Allo, allogeneic. (c) The dot plots demonstrate how CD44high and CD44low $T$ cells can be distinguished by flow cytometric analysis in the spleen of a normal mouse and that CD44low populations represent naive CD4 ${ }^{+}$ T cells, which express $\mathrm{CD} 62 \mathrm{~L}$, or naive $\mathrm{CD} 8^{+} \mathrm{T}$ cells, which do not express CD122. CBA/J mice were transplanted as described in Figure 1a without the addition of T cells, and splenocytes were analyzed on day 28 . Naive CD4 cells were defined as CD4 ${ }^{+}$CD 44 low, memory/activated (MEM/ACT) CD4 cells were defined as CD4 ${ }^{+} C D 44^{\text {high }}$, naive $C D 8$ cells were defined as CD8 ${ }^{+} C D 44^{\text {low }}$, and memory/activated CD8 cells were defined as $\mathrm{CD} 8{ }^{+} \mathrm{CD} 44^{\text {high }}$. (d) $\mathrm{CBA} / \mathrm{J}$ mice were transplanted as described in Figure 1a without the addition of T cells and received 10 $\mu \mathrm{g} /$ day IL-7 or PBS (control) on days 21-27 by intraperitoneal injection. Splenocytes were analyzed at different timepoints after transplant. Values represent the mean cell number $\pm \operatorname{SEM}(n=6-20) .{ }^{*} P<0.05$. 
a
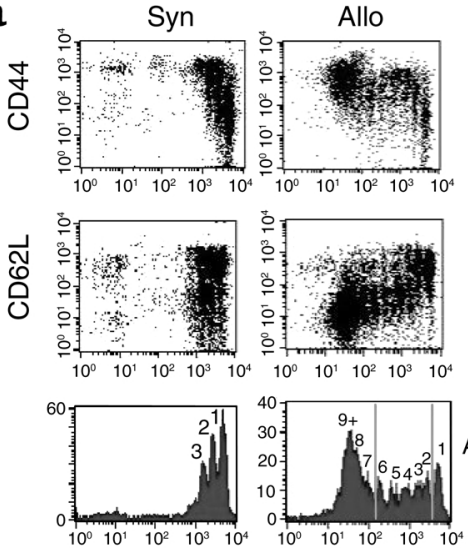

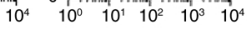

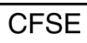

b

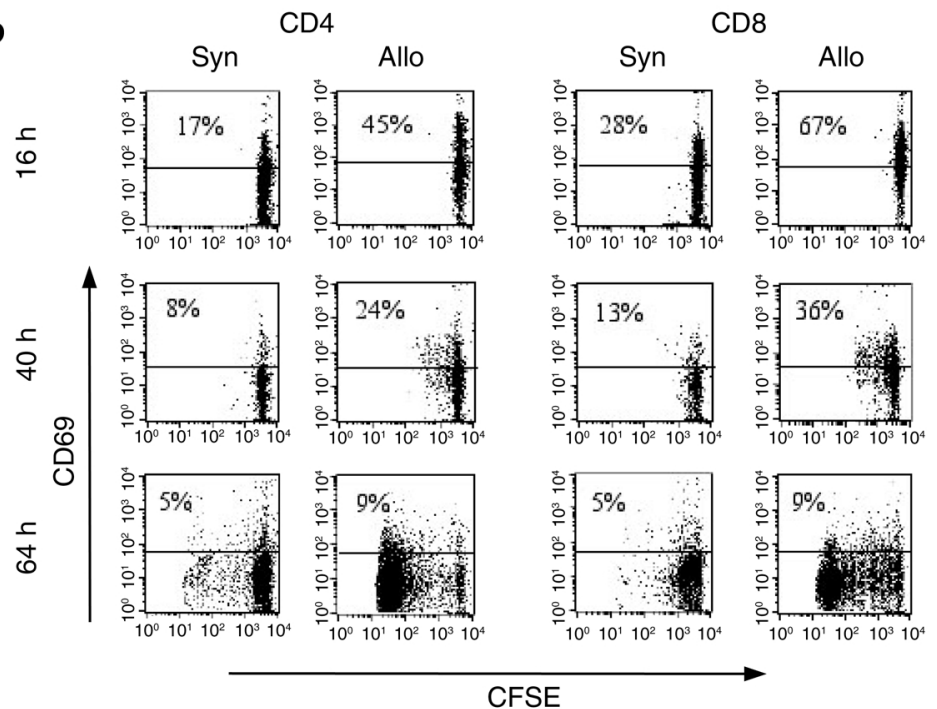

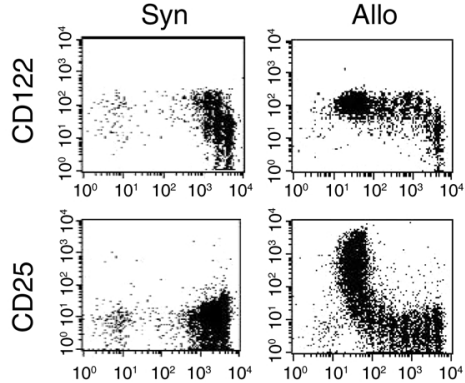

Syn: B6 (BM) + B6 (Ly5.1) T cells $\rightarrow$ B6 Allo: $\mathrm{B} 6(\mathrm{BM})+\mathrm{B} 6(\mathrm{Ly} 5.1) \mathrm{T}$ cells $\rightarrow \mathrm{C} 3 \mathrm{FeB} 6 \mathrm{~F}$ $64 \mathrm{~h} \mathrm{CD8}+\mathrm{T}$ cells

CD8 T cells

to
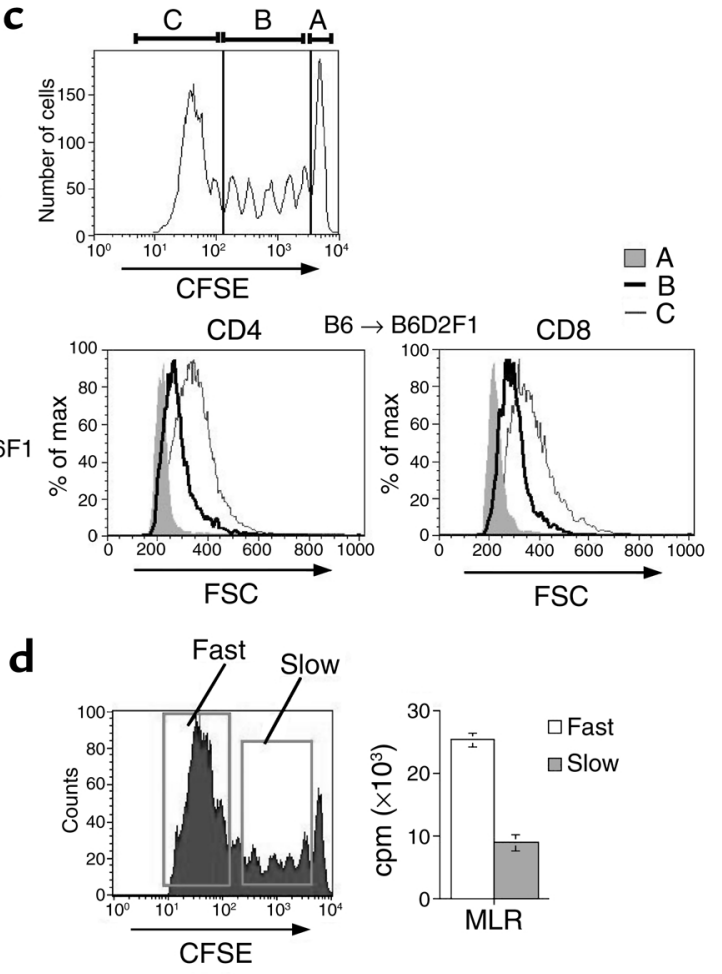

\section{Figure 2}

Alloreactive and nonalloreactive donor T cells can be distinguished by their phenotype and proliferation kinetics. (a and $\mathbf{b})$ Lethally irradiated (1,300 cGy) C3FeB6F1 (allogeneic, Allo) or B6 (syngeneic, Syn) recipients were transplanted with B6 BM (5 $\times 10^{6}$ ) and CFSE-labeled B6 $\left(\right.$ Ly $\left.5.1^{+}\right)$purified T cells $\left(2 \times 10^{7}\right)$. At various timepoints after BMT, recipients were sacrificed and splenocytes were stained with antiCD8, -CD25, -CD44, -CD62L, and -CD122 antibodies. Flow cytometric analysis is shown for expression of these antibodies on donor CD8 ${ }^{+}$ T cells 64 hours after BMT (a).CD69 expression on donor CD4 and CD8 T cells in the spleen was determined 16 hours, 40 hours, and 64 hours after BMT (b). (c) Lethally irradiated (750 cGy) B6D2F1/J recipients were transplanted with CFSE-labeled B6 purified T cells (2 $\times 10^{7}$ ). After 64 hours, mice were sacrificed, splenocytes were stained with anti-CD4 and -CD8 antibodies, and FSC intensity was determined. A: nondividing cells; B: slow proliferating cells; C: fast proliferating cells. FSC, forward scatter; \% of max, \% of maximum number of the cells per group. (d) Lethally irradiated ( 750 cGy) C3FeB6F1 recipients were transplanted with CFSE-labeled B6 purified T cells $\left(2 \times 10^{7}\right)$. After 64 hours, mice were sacrificed and splenocytes were sorted according to CFSE intensity, shown in a histogram plot as fast- and slow-proliferative cells. Cells were incubated with irradiated C3FeB6F1 splenocytes as stimulators for 5 days. IL-2 (20 IU/ml) was added after 72 hours, and proliferation was determined by ${ }^{3} \mathrm{H}$-thymidine incorporation.

tribute to $T$ cell reconstitution, especially in older recipients with diminished thymic function (17); and (c) donor hematopoietic stem cell-derived $T$ cells, newly derived $\mathrm{T}$ cells that originate from the transplanted donor hematopoietic stem cells and have been generated through thymic (and possibly also through extrathymic) differentiation.

To assess the proliferative activity and cell surface antigen expression patterns of alloreactive and nonalloreactive donor $\mathrm{T}$ cells after transplantation, we transferred CFSE-labeled purified splenic T cells from B6 (Ly5.1) donors into lethally irradiated syngeneic (B6) and allo- geneic (C3FeB6F1) recipients and analyzed the number of cell divisions and cell surface antigen expression daily for 7 days (Figure 2a, 64 hours, and data not shown). When transferred into a lethally irradiated syngeneic recipient, B6 (Ly5.1) T cells undergo not more than three cell cycles in 64 hours, which is in agreement with the slow proliferation described previously for homeostatic proliferation of mature $T$ cells in lymphopenic hosts (38-42).

These $\mathrm{T}$ cells acquire a partially activated memorylike cell surface expression pattern during their homeostatic proliferation, consisting of increased expression of CD44 and CD122. However, CD62L was downregu- 
lated on less than $40 \%$ of the cells and CD25 expression was not increased.

CFSE-labeled T cells transferred into lethally irradiated allogeneic recipients could be separated into two populations of cells based upon their proliferation and cell surface expression. The first population consisted of cells that had undergone more than seven cell cycles in 64 hours and acquired a fully activated cell surface expression pattern with increased expression of CD44, CD122, and CD25, and decreased expression of CD62L. Based upon their rapid proliferation with a cell cycle duration of 6-9 hours and their acquisition of an activated cell surface antigen pattern, which is identi- cal to the antigen-driven rapid proliferative response of alloreactive $\mathrm{T}$ cells described previously $(43,44)$, we conclude that these cells represent alloreactive $T$ cells that respond to host antigens.

The second population of $\mathrm{T}$ cells has slower proliferative kinetics (not more than three cell cycles in 64 hours) similar to those of $\mathrm{T}$ cells transferred into syngeneic hosts. These slowly proliferating $\mathrm{T}$ cells in allogeneic recipients acquire a cell surface expression pattern similar to that of $T$ cells transferred into syngeneic recipients: increased CD44 and CD122 expression, but only limited downregulation of CD62L and no increase of CD25 expression. Based upon their similarity in pro-
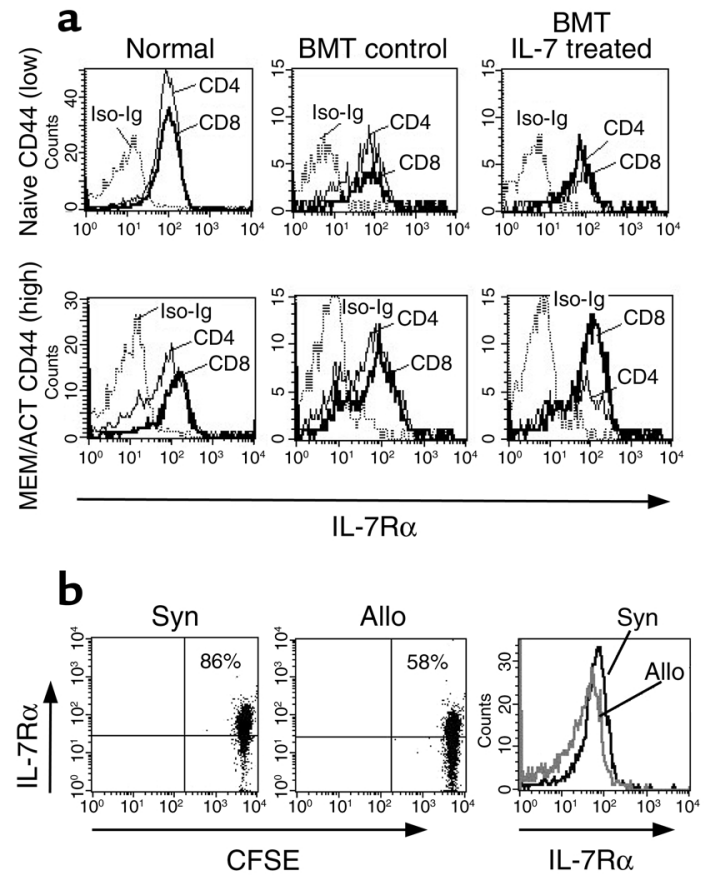

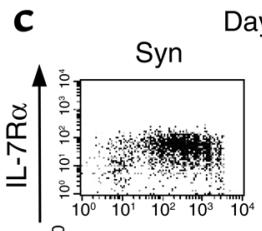

Day 7
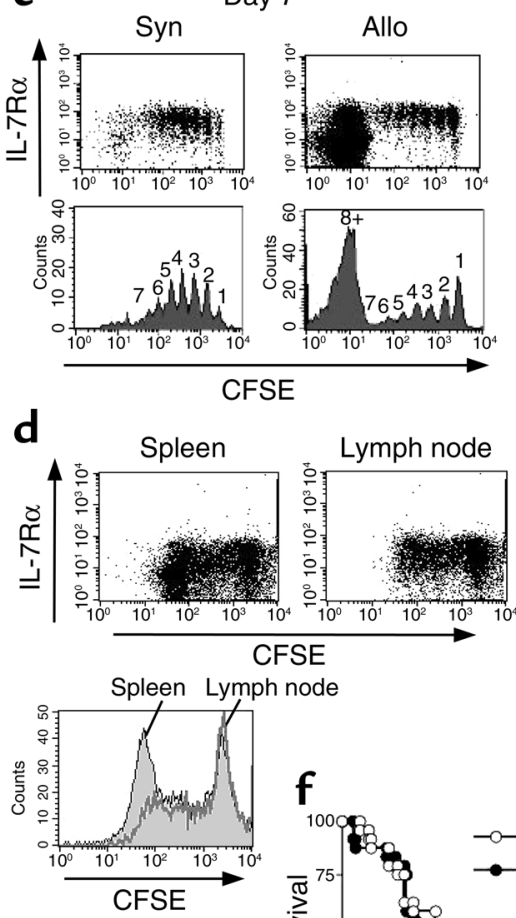

f
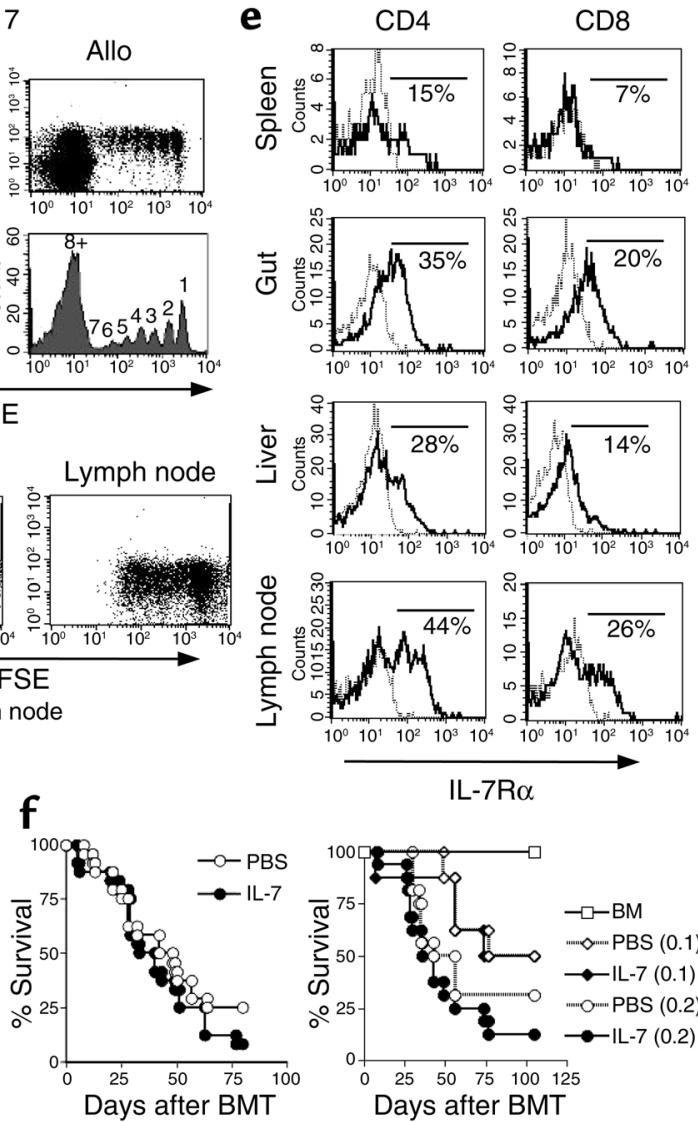

IL-7R $\alpha$

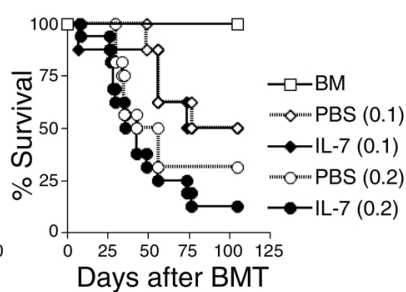

Figure 3

IL-7R $\alpha$ expression is downregulated on alloreactive T cells and IL-7 does not exacerbate the development of GVHD. (a) Lethally irradiated (1,300 cGy) CBA recipients were transplanted with B10.BR TCD-BM. IL-7 (10 $\mu \mathrm{g} / \mathrm{day})$ or PBS (control) was administered by intraperitoneal injection on days 21-27 after allogeneic BMT. Animals were sacrificed on day 28 and IL-7R $\alpha$ expression was determined on donor-derived splenic $\mathrm{CD}^{+}$and $\mathrm{CD}^{+}$cells in IL-7-treated, PBS (control), and age-matched nontransplanted mice by flow cytometric analysis. Naive and memory/activated cells and donor/host origin were defined as in Figure 1. Iso-Ig, isotype control for the anti-IL-7R $\alpha$ antibody. (b and c) BMT was performed as described in Figure 2a. Spleens were harvested from mice at 16 hours and on day 7 , and stained with anti-CD 8 and -IL-7R $\alpha$ antibodies. (d) Sublethally irradiated (750 cGy) C3FeB6F1 recipients were infused with CFSE-labeled B6 purified T cells $\left(2 \times 10^{7}\right)$. Spleen and superficial lymph nodes (axillary and inguinal) were harvested at day 3 and cells underwent flow cytometric analysis with antiCD8 and -IL-7R $\alpha$ antibodies to determine the number of cell divisions and IL-7R $\alpha$ expression of CD8 $8^{+}$T cells. (e) Lethally irradiated (1,300 cGy) CBA mice were transplanted with B10.BR TCD-BM $\left(5 \times 10^{6}\right)$ with T cells $\left(0.5 \times 10^{6}\right)$. Mice were sacrificed at day 7 or day 14 after BMT. Spleen, gut, liver, and lymph nodes were harvested and mononuclear cells were obtained. Cells were stained with anti-CD4, -CD8, and -IL-7R $\alpha$ antibodies for flow cytometric analysis. Representative histograms of four mice are shown. Dotted lines indicate isotype control for IL-7R $\alpha$. (f) Lethally irradiated (1,300 cGy) CBA mice were transplanted with B10.BR TCD-BM $\left(5 \times 10^{6}\right)$ and varying T cell doses: $0.5 \times 10^{6}($ left graph), $0.2 \times 10^{6}$ (right graph, circles), and $0.1 \times 10^{6}$ (right graph, diamonds). IL-7 (10 $\mu \mathrm{g} / \mathrm{day}$ ) or PBS (control) was administered by intraperitoneal injection from day 0 to day 7 after allogeneic BMT. Open symbols represent the PBS (control) groups, and filled symbols represent the IL-7-treated groups. Kaplan-Meier survival curves are shown $(n=8-24)$. 

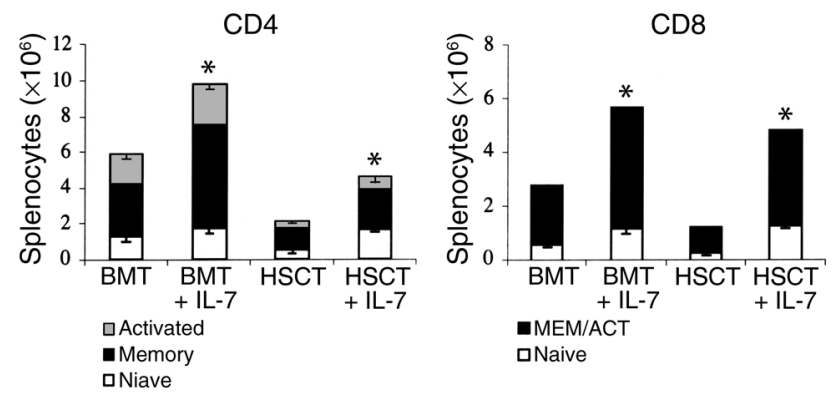

Figure 4

Most de novo-generated T cells after allogeneic BMT with purified hematopoietic stem cells have a memory/activated phenotype. Lethally irradiated (1,300 cGy) CBA/J mice were transplanted with either B10.BR TCD-BM (allogeneic BMT) or lineage-negative SCA- ${ }^{+}{ }^{+}$kit $^{+}$B10.BR BM cells $\left(2 \times 10^{4}\right)$. IL-7 $(10 \mu \mathrm{g} /$ day) or PBS (control) was administered by intraperitoneal injection from day 21 to day 28 after allogeneic BMT, and from day 28 to day 35 after allogeneic SCT. Animals were sacrificed and harvested on day 28 (BMT) and day 35 (SCT). Absolute numbers of specific donor-derived cell populations were calculated from total cell counts and percentages of $T$ cells by flow cytometric analysis. Naive $C D 4^{+} \mathrm{T}$ cells were defined as CD44 $4^{\text {low }} \mathrm{CD} 62 \mathrm{~L}^{\text {high }}$, activated $\mathrm{CD} 4^{+} \mathrm{T}$ cells as $\mathrm{CD} 44^{\text {high }} \mathrm{CD} 62 \mathrm{~L}^{\text {high }}$, memory $\mathrm{CD}^{+} \mathrm{T}$ cells as $\mathrm{CD} 44^{\text {high }} \mathrm{CD} 6 \mathrm{~L}^{\text {low }}$, naive $\mathrm{CD} 8^{+} \mathrm{T}$ cells as CD44 $4^{\text {low }}$, and memory/activated $C D 8^{+} T$ cells as CD44high. Values represent the mean cell number \pm SEM (SCT: $n=3$; BMT: $n=16$ ).

liferation kinetics and cell surface expression pattern, we conclude that these cells represent nonalloreactive $\mathrm{T}$ cells undergoing homeostatic proliferation.

We also assessed the expression of the early activation antigen $\mathrm{CD} 69$, and found increased expression on $\mathrm{CD}^{+}$and $\mathrm{CD}^{+}{ }^{+} \mathrm{T}$ cells transferred to syngeneic or allogeneic recipients at 16 hours; this increase disappeared by the 40 -hour timepoint (Figure $2 \mathrm{~b}$ ).

The differences in activation state between nonproliferating, nonalloreactive $T$ cells and alloreactive $T$ cells are further illustrated by differences in cell size as determined by flow cytometry (Figure 2c). Alloreactive $\mathrm{T}$ cells have a larger, blast-like size than nonalloreactive proliferating $T$ cells, which are only slightly larger than nonproliferating $\mathrm{T}$ cells.

To further define the functional differences between the fast-dividing alloreactive and slow-dividing nonalloreactive $\mathrm{T}$ cells, we purified fast-proliferative and slow-proliferative $T$ cells from recipients of allogeneic CFSE-labeled $\mathrm{T}$ cells by flow cytometry and incubated these populations with irradiated host cells for 5 days. We found that alloreactive fast-dividing $\mathrm{T}$ cells had a significantly greater proliferative response to host antigen than did the slower-dividing nonalloreactive $\mathrm{T}$ cells (Figure $2 \mathrm{~d}$ ).

IL-7R is downregulated in alloreactive donor T cells. To assess the sensitivity of these nonalloreactive and alloreactive $T$ cells to IL-7 administration, we analyzed the expression of the IL-7 receptor $\alpha$ chain (IL-7R $\alpha$, CD127). We found that most naive $\mathrm{CD} 44^{\text {low }}$ and memory/activated $\mathrm{CD} 44^{\text {high }}$ $\mathrm{CD}^{+}$and $\mathrm{CD}^{+} \mathrm{T}$ cells in normal mice expressed IL-7R (Figure 3a). We then analyzed the IL-7R $\alpha$ expression on these same populations of naive and memory/activated $\mathrm{T}$ cells in recipients of allogeneic TCD-BMT (which incur no GVHD) and found IL-7R $\alpha$ expression on the majority of cells even in recipients treated with IL-7.

We also analyzed IL-7R $\alpha$ expression on CFSE-labeled donor $T$ cells transferred to syngeneic or allogeneic recipients and found intact IL-7R $\alpha$ expression on homeostatically proliferating $\mathrm{T}$ cells in syngeneic or allogeneic recipients even after more than five cell cycles (Figure 3 , $\mathrm{b}$ and $\mathrm{c}$ ). When we analyzed CFSE-labeled purified $\mathrm{T}$ cells 16 hours after injection into lethally irradiated recipients, we observed a decrease in IL-7R $\alpha$ expression on donor $\mathrm{T}$ cells transplanted into allogeneic recipients compared with syngeneic recipients: $51 \%$ versus $83 \%$ for $\mathrm{CD}^{+} \mathrm{T}$ cells and $58 \%$ versus $86 \%$ for $\mathrm{CD}^{+} \mathrm{T}$ cells (data not shown and Figure $3 \mathrm{~b}$ ). Moreover, alloreactive T cells that had gone through more than eight cell divisions in 7 days, expressed low levels of IL-7R $\alpha$ (Figure 3c). When we compared the proliferation and IL-7R $\alpha$ expression on CFSE-labeled $T$ cells in the lymph nodes and the spleen 3 days after infusion, we noted only a small fraction of fast-proliferating alloreactive $T$ cells in the lymph nodes compared with the spleen (Figure $3 \mathrm{~d}$ ). In recipients with clinical GVHD, IL-7R $\alpha$ expression on T cells in the target organs of GVHD (such as gut and liver) was evaluated, and donor-derived TCR- $\alpha \beta^{+}$intraepithelial lymphocytes in the gut and T cells in the liver were found to have downregulated their IL-7R $\alpha$ expression on day 7 (gut) or day 14 (spleen, lymph node, and liver) (Figure 3e).

These data suggest that alloreactive $T$ cells are not sensitive to IL-7 and therefore that IL-7 administration should have no (or little) effect on the development of GVHD. We have previously published that IL-7 administration had no effect on GVHD mortality in two different GVHD models. However, a recent study showed increased GVHD mortality in IL-7-treated recipients (45). The authors suggested that the difference could be due to the fact that in our previous study all experimental groups had high mortality (75-100\%) from GVHD, which could impair the sensitivity to find smaller differences in GVHD mortality between groups. Therefore, we studied GVHD mortality in recipients of varying doses of $T$ cells, but could still not detect a significant increase in GVHD mortality between IL-7-treated and control groups, even when GVHD mortality was only $50 \%$ after more than 100 days (Figure 3f).

Donor-derived peripheral $\mathrm{T}$ cells in recipients of purified allogeneic hematopoietic stem cells have predominantly a memory-like phenotype. As stated before, previous studies have suggested that the predominance of $T$ cells with a memory/activated phenotype after allogeneic BMT is due to the homeostatic expansion of nonalloreactive mature $\mathrm{T}$ cells, which are transferred with the allograft. However, in our experiments with TCD allografts (Figure 1c), we noted that in the first weeks after transplant, donor $\mathrm{CD} 4^{+}$and $\mathrm{CD} 8^{+} \mathrm{T}$ cells are mostly of a memory/activated phenotype. To rule out that this early reconstitution of memory/activated $T$ cells was due to homeostatic expansion of a few contaminating mature nonalloreactive donor $\mathrm{T}$ cells that had escaped the $\mathrm{T}$ cell depletion, we repeated our $\mathrm{T}$ cell reconstitution 
experiments with highly purified allogeneic lineage-negative SCA- $1^{+} \mathrm{c}-\mathrm{kit}{ }^{+}$hematopoietic stem cells (Figure 4). At day 28 after transplant we again found a predominance of memory/activated $\mathrm{CD}^{+}$and $\mathrm{CD}^{+} \mathrm{T}$ cells. IL-7 administration to recipients of allogeneic hematopoietic stem cells resulted not only in enhanced donor $\mathrm{T}$ cell reconstitution, but also significantly increased naive donor $\mathrm{CD}^{+}$and $\mathrm{CD}^{+} \mathrm{T}$ cells. We conclude from these reconstitution experiments with purified allogeneic hematopoietic stem cells that early $\mathrm{T}$ cell reconstitution with mostly memory/activated T cells can also occur in the absence of mature nonalloreactive donor $T$ cells.

Thymocytes can undergo homeostatic proliferation upon transfer in lethally irradiated syngeneic or allogeneic recipients. To explain the predominance of memory-like $\mathrm{T}$ cells in recipients of allogeneic hematopoietic stem cells, we hypothesized that recent thymic emigrants (RTEs) with a naive phenotype in the lymphopenic environment of an allogeneic recipient will undergo homeostatic expansion and acquire a memory-like phenotype (CD44 high$\mathrm{CD}_{122}$; see Figure 2a) similar to that of mature T cells, which undergo homeostatic proliferation.

To test this hypothesis, we transferred thymocytes from $\mathrm{CBA} / \mathrm{J}$ donors or from recipients of allogeneic $(\mathrm{B} 10 . \mathrm{BR} \rightarrow$ CBA/J) TCD-BMT into lethally irradiated CBA/J recipients, and assessed their proliferation 5 days later. When we compared the transfer of CFSE-labeled thymocytes (Figure 5a) and splenocytes (Figure 5b) from CBA/J donors into a lethally irradiated CBA/J host, we observed an identical slow homeostatic proliferation (with a cell cycle longer than 24 hours) in both cell populations. This was true for both $\mathrm{CD}^{+}$and $\mathrm{CD}^{+} \mathrm{T}$ cells, and we did not detect any $\mathrm{CD}^{+} \mathrm{CD}^{+}$double-positive cells in recipients of thymocytes. All slowly proliferating $\mathrm{CD}^{+}$and $\mathrm{CD}^{+}$thymocytes had upregulated CD44 ${ }^{+}$expression, which is consistent with homeostatic proliferation (data not shown). These results demonstrated that thymocytes can undergo homeostatic proliferation in a lymphopenic environment.

We then performed similar experiments with CFSE-labeled thymocytes and purified splenic $T$ cells from recipients of allogeneic $(\mathrm{B} 10 . \mathrm{BR} \rightarrow \mathrm{CBA} / \mathrm{J})$ TCD-BMT transferred into a lethally irradiated CBA/J host (Figure 5, $\mathrm{c}$ and d). We found that both populations could undergo homeostatic proliferation, although we noted a second rapidly proliferating population among transferred thymocytes. As expected for homeostatically proliferating cells, we observed increased expression of CD44 and CD122 in the slow-proliferating populations of transferred thymocytes (data not shown). When we compared the two rapid- and slow-proliferating populations of thymocytes with the

\section{Figure 5}

proliferation kinetics of syngeneic or allogeneic T cells transferred into lethally irradiated recipients, we noted that the rapidly proliferating thymocytes had the same proliferation pattern as allogeneic T cells (Figure 5e), whereas the slowly proliferating thymocytes had proliferation kinetics similar to those of syngeneic T cells. These rapidly proliferating thymocytes could represent de novo-generated alloreactive thymocytes or mature alloreactive $T$ cells that had been transferred with the TCD allograft and had invaded the thymus.

We conclude from these studies that thymocytes have a capacity to undergo homeostatic expansion similar to that of splenic $T$ cells in lymphopenic lethally irradiated syngeneic or allogeneic recipients. These data suggest that RTEs in a lymphopenic recipient of allogeneic BMT could acquire a memory-like phenotype and undergo homeostatic proliferation, which could explain the predominance of donor-derived memory-like T cells even in recipients of purified donor hematopoietic stem cells.

We also assessed the effects of IL-7 administration on the homeostatic proliferation of CFSE-labeled thymocytes transferred into lethally irradiated syngeneic recipients. Four days after transfer, we observed an increased fraction of slowly proliferating $\mathrm{CD}^{+}$and $\mathrm{CD}^{+}$thymocytes in the IL-7-treated recipients (data not shown). These results provide further evidence that IL-7 administration can stimulate homeostatic proliferation of RTEs.

IL-7 administration enhances proliferation of donor-derived memory-like peripheral T cells after allogeneic BMT. To further analyze the effects of IL-7 administration on peripheral $\mathrm{T}$ cell reconstitution in recipients of allogeneic BMT, we assessed the fraction of peripheral

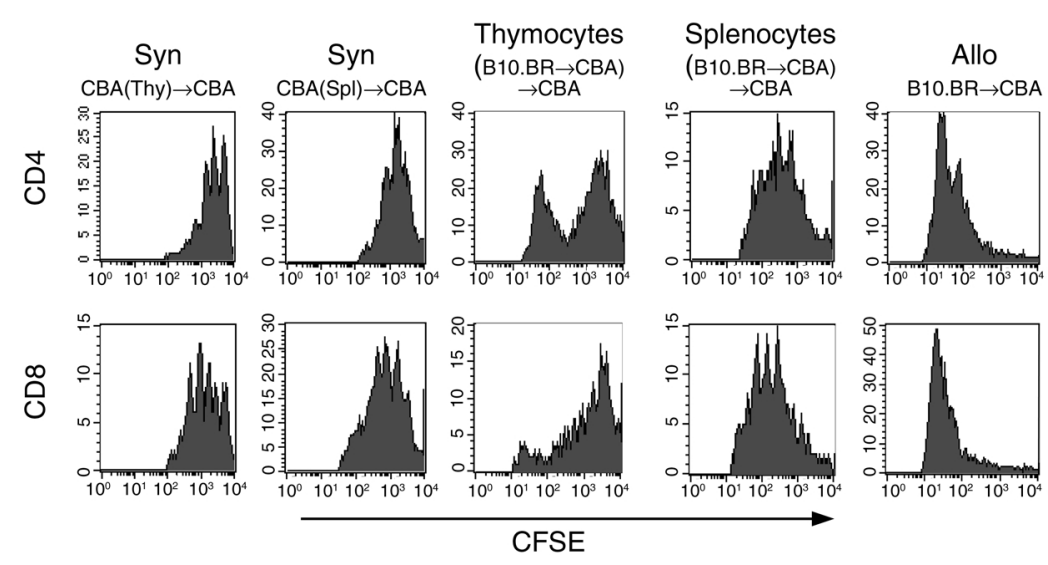

De novo-generated T cells undergo homeostatic expansion in the recipient of an allogeneic BMT. (a and b) CFSE-labeled thymocytes (Thy) (a) and splenocytes (Spl) (b) (107 each) from syngeneic donors (Syn) were transferred into lethally irradiated CBA/J recipients. On day 5 , splenocytes from the recipients were harvested and stained with anti-CD4 and -CD8 antibodies for flow cytometric analysis. (c-e) Lethally irradiated CBA/J mice were transplanted with B10.BR TCD-BM and sacrificed on day 28 after allogeneic BMT. Thymocytes (c) and splenic T cells (d) were harvested, pooled, and labeled with CFSE, and $10^{7}$ cells were infused into irradiated CBA/J mice. On day 5, splenocytes from the recipients were harvested and stained with anti-CD4 and -CD8 antibodies for flow cytometric analysis. Infusion with CFSE-labeled B10.BR splenic T cells was performed as the allogeneic control (e). CBA, CBA/J. 

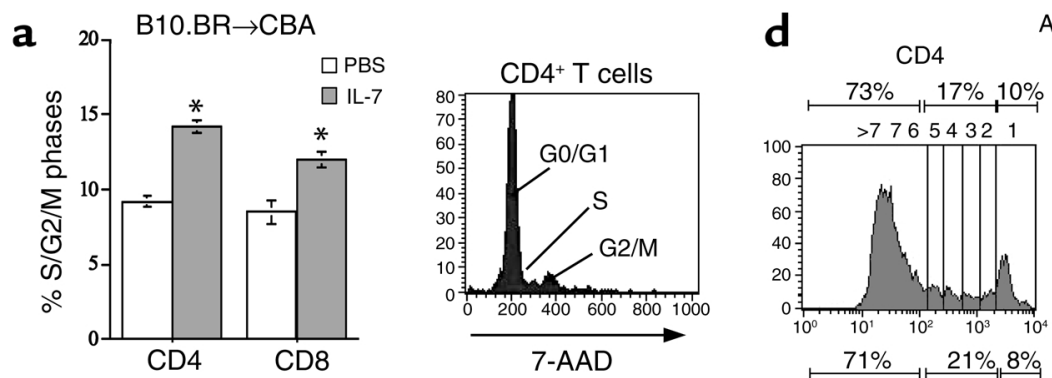

Allo
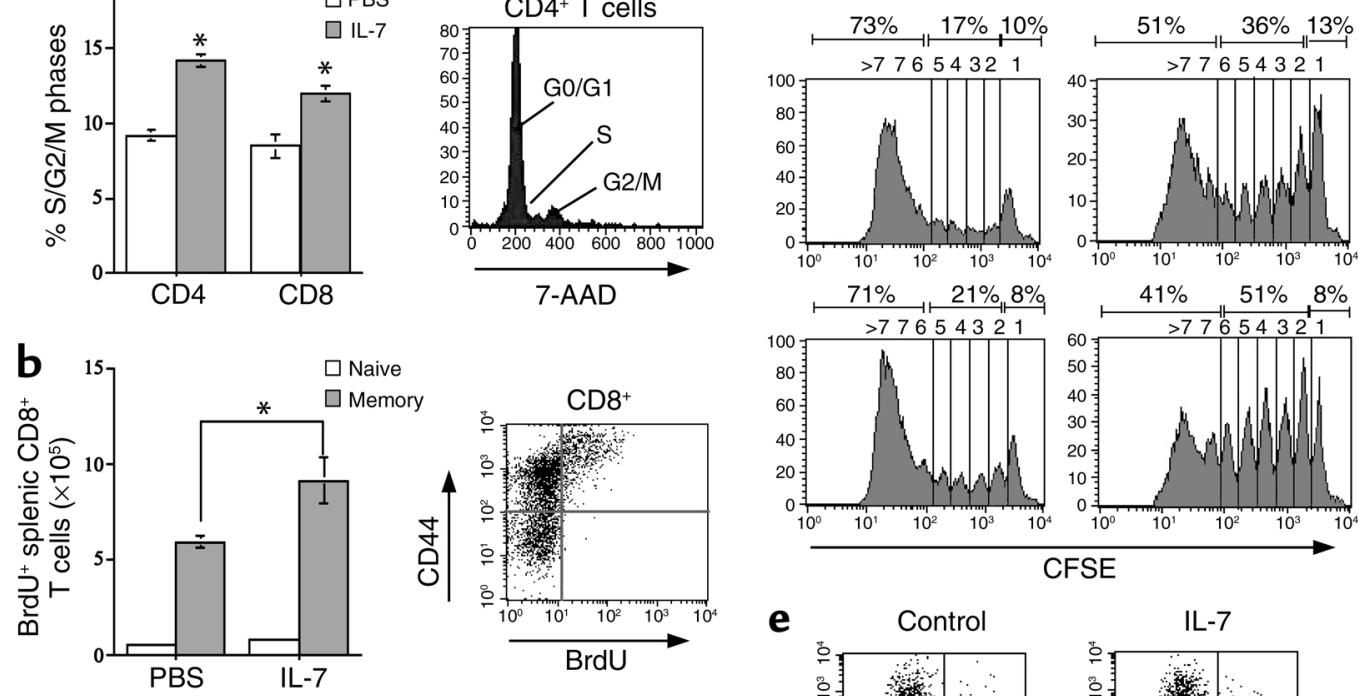

C

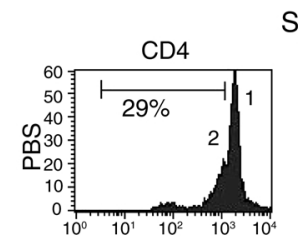

Syn
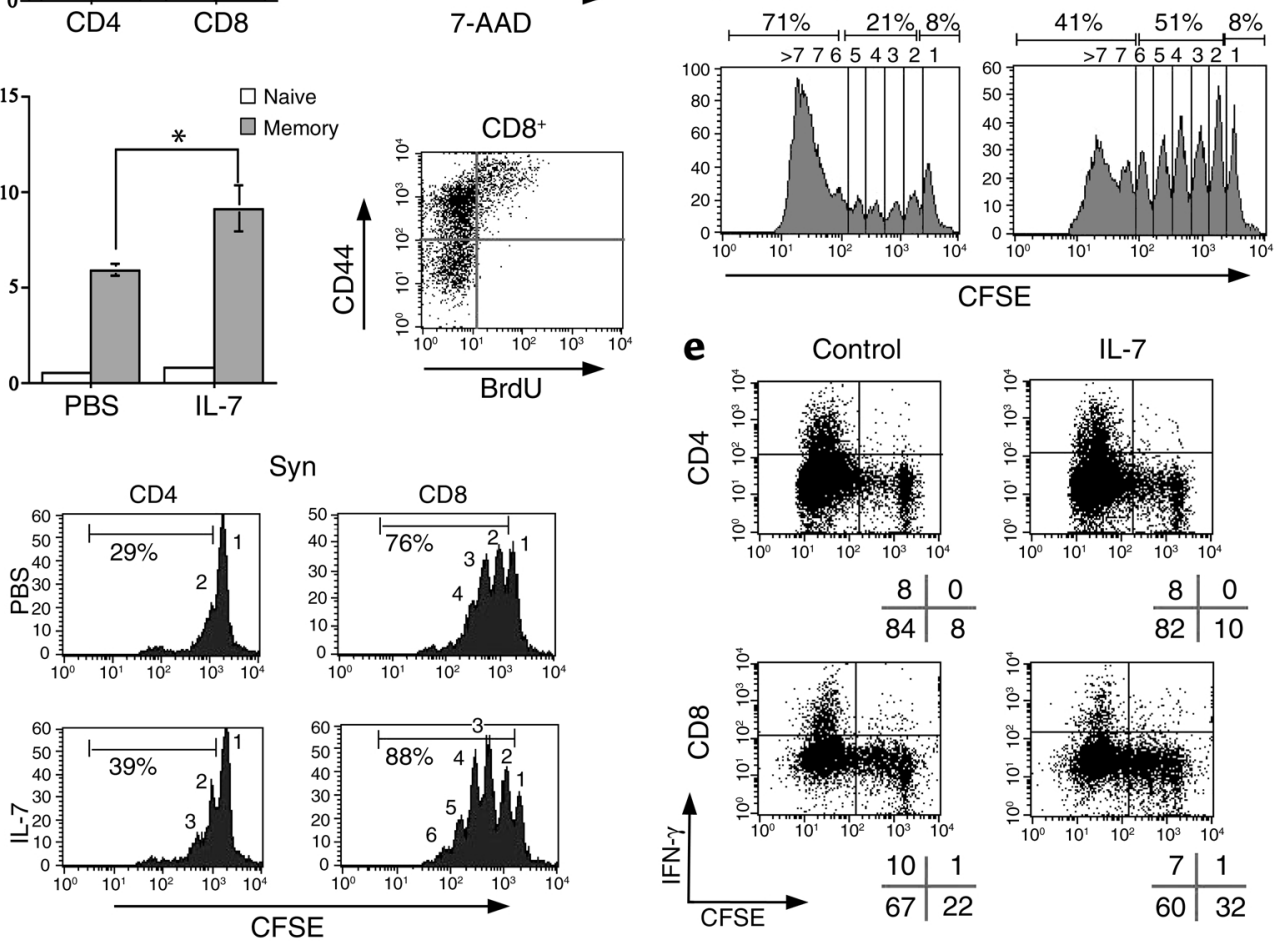

\section{Figure 6}

Posttransplant IL-7 administration increases the proliferation of nonalloreactive donor T cells in recipients of allogeneic BMT. (a) Lethally irradiated CBA/J recipients were transplanted with B10.BR TCD-BM $\left(5 \times 10^{6}\right)$ and received $10 \mu \mathrm{g} /$ day IL-7 or PBS (control) on days $21-27$. Animals were sacrificed on day 28 and splenocytes were stained with cell surface antibodies (anti-CD4, -CD8, and -Ly9.1), followed by fixation, permeabilization, and intracellular staining with 7-AAD for cell cycle analysis. The values shown represent the mean percentage \pm SEM of donor $\mathrm{CD}^{+}$or $\mathrm{CD}^{+} \mathrm{T}$ cells in $\mathrm{S} / \mathrm{G} 2 / \mathrm{M}$ phase with $P$ values comparing IL-7-treated with PBS-treated groups (four mice per group). ${ }^{*} P<0.05$. (b) Mice were transplanted as described in $\mathbf{a}$, and $\mathrm{BrdU}$ was added to their drinking water at a concentration of $0.8 \mathrm{mg} / \mathrm{ml}$ on days $15-33$ after allogeneic BMT. The mice also received $1 \mu \mathrm{g} /$ day IL-7 or PBS (control) on days 15-33. Splenocytes were harvested at day 33 and stained with anti-CD4, CD8, -CD44, and -BrdU antibodies. The values shown represent the mean percentage $\pm \mathrm{SEM}$ of donor naive or memory $\mathrm{CD} 8^{+} \mathrm{T}$ cells that are $\mathrm{BrdU}^{+}$, with $P$ values comparing IL-7-treated with PBS-treated groups (four mice per group). (c and d) Sublethally irradiated B6 $\left(\right.$ Ly $\left.5.1^{+}\right)$(syngeneic) or C3FeB6F1 (allogeneic) recipients were infused with CFSE-labeled B6 purified T cells $\left(2 \times 10^{7}\right)$. The recipients received $10 \mu \mathrm{g} /$ day IL-7 or PBS (control) on days $0-3$. On day 3, splenocytes were harvested and stained with anti-CD4 and anti-CD8 antibodies for flow cytometric analysis. Results shown are representative of three duplicate experiments. (e) Splenocytes were harvested from C3FeB6F1 (allogeneic) recipients as in $\mathbf{d}$, and incubated with PMA $(10 \mathrm{ng} / \mathrm{ml})$ and ionomycin $(2 \mu \mathrm{M})$ for 5 hours. Brefeldin A was added during the last 3 hours to inhibit IFN- $\gamma$ secretion. Cells were harvested and stained with anti-CD4 and anti-CD8 antibodies, then washed, fixed, permeabilized, and stained intracellularly with anti-IFN- $\gamma$ antibody.

donor $\mathrm{T}$ cells in $\mathrm{S} / \mathrm{G} 2 / \mathrm{M}$ phase and found a significant increase in IL-7-treated recipients (Figure 6a). These data suggest that IL-7 has a proliferative effect on peripheral $\mathrm{T}$ cells after allogeneic BMT. This proliferative effect of posttransplant IL-7 administration affected mostly memory-like $\mathrm{T}$ cells, as demonstrated with pulse-chase BrdU labeling studies (Figure 6b). We further assessed the specific effects of IL-7 administration on homeostatic proliferation of donor $\mathrm{T}$ cells and found an increase in the number of cell divisions of
$\mathrm{CD}^{+}$and $\mathrm{CD}^{+} \mathrm{T}$ cells in lethally irradiated syngeneic recipients (Figure 6c). In IL-7-treated allogeneic recipients, we observed a remarkable increase in nonalloreactive slowly proliferating $\mathrm{CD}^{+} \mathrm{T}$ cells, whereas IL-7 administration (again) did not increase the proliferation of the alloreactive cells (Figure $6 \mathrm{~d}$ ). When we determined the potential to secrete IFN- $\gamma$, we found, as expected, that only fast-dividing alloreactive $\mathrm{T}$ cells demonstrated increased IFN- $\gamma$ secretion upon a short stimulation with PMA-ionomycin (Figure 6e). IL-7 
administration to the recipients of CFSE-labeled T cells did not affect IFN- $\gamma$ secretion by alloreactive T cells.

IL-7 administration decreases peripheral $T$ cell apoptosis in middle-aged recipients of allogeneic BMT. To test a possible antiapoptotic effect of IL-7 on peripheral T cell reconstitution after allogeneic BMT, we assessed the number of apoptotic splenic $\mathrm{T}$ cells in young (3-month-old) and middle-aged (9-month-old) allogeneic recipients (Figure 7 , $a$ and $b$ ). We found an increased number of apoptotic $\mathrm{CD}^{+}$and $\mathrm{CD}^{+} \mathrm{T}$ cells in middle-aged (but not young) recipients of allogeneic BMT that was significantly decreased by IL-7 administration. We determined Bcl-2 expression levels by flow cytometry and found a decrease in Bcl-2+ cells in peripheral T cells of allogeneic BMT recipients compared with normal animals, especially in middle-aged recipients. However, we could not detect a significant increase in Bcl-2 $2^{+} \mathrm{T}$ cells in IL-7treated middle-aged recipients of allogeneic BMT.

\section{Discussion}

The majority of donor-derived T cells in the first weeks (mouse) or months (man) after allogeneic HSCT have a memory-like phenotype, and this has been interpreted previously as evidence for a predominance of antigen-driven peripheral expansion of mature $T$ cells from the allograft and a deficit in thymic output in the posttransplant period $(14,15)$. A number of studies measuring RTEs by TCR rearrangement excision circles (TRECs) have questioned the lack of posttransplant thymic function and were able to demonstrate significant thymic output even in older recipients of allogeneic HSCT (46-49). Murine studies have demonstrated that aged recipients of $\mathrm{T}$ cell-depleted BMT display normal thymic subsets, appropriate negative selection, and significant thymic T cell output (50\% of the thymic output of young recipients) (17).

Our results regarding the predominance of memorylike donor $\mathrm{T}$ cells after transplantation of purified hematopoietic stem cells challenge the hypothesis that memory-like donor $T$ cells during posttransplant reconstitution are being generated exclusively by the expansion of mature $\mathrm{T}$ cells in the allograft. Moreover, our data are in agreement with human studies regarding $T$ cell reconstitution following an allogeneic peripheral blood stem cell transplant with CD34+-selected cells, which demonstrated that most $\mathrm{CD}^{+} \mathrm{T}$ cells in the posttransplant period expressed CD45RO (50).

Our data suggest that the homeostatic expansion of peripheral $\mathrm{T}$ cells in a lymphopenic recipient involves both thymic emigrants and nonalloreactive $T$ cells in the allograft and has the characteristics of homeostatic expansion (slow proliferation kinetics and partially activated cell surface antigen pattern) instead of classic antigen-driven $T$ cell proliferation (with rapid proliferation and full activated cell surface antigen pattern).

In agreement with our findings that RTEs can undergo homeostatic proliferation, Le Campion et al. (51) have demonstrated recently that RTEs in neonatal mice undergo homeostatic proliferation. Interestingly, neo- natal RTEs entering into the periphery of a neonatal mouse maintained their naive phenotype during proliferation, whereas RTEs that exited from a neonatal thymic graft in an adult mouse acquired an activated phenotype during homeostatic proliferation in the adult lymphoid environment.

Goldrath et al. showed that the memory phenotype $\left(\mathrm{CD} 44^{+} \mathrm{CD} 122^{+} \mathrm{Ly} 6 \mathrm{C}^{+}\right)$acquired by naive $\mathrm{CD}^{+} \mathrm{T}$ cells during homeostatic-driven proliferation in sublethally irradiated syngeneic hosts was transient, and naive $\mathrm{T}$ cells started to accumulate around 3 weeks after transfer of spleen and lymph node cells (52). This was explained as the reversion of memory to naive phenotype by homeostatic $\mathrm{CD}^{+} \mathrm{T}$ cells. However, several studies have suggested that this reversal does not occur, and that the increase of naive $T$ cells over time is due to de novo $T$ cell development in the thymus (53-55). This would suggest that homeostasis-driven proliferation will replete only the memory $T$ cell pool, and thymopoiesis is required for reconstitution of the naive $T$ cell pool. We hypothesize that one reason for the delay in reconstitution of the naive $T$ cell pool is related to the conversion of RTEs to memory-like T cells, which will then undergo homeostatic proliferation until the total $\mathrm{T}$ cell pool has been repleted.
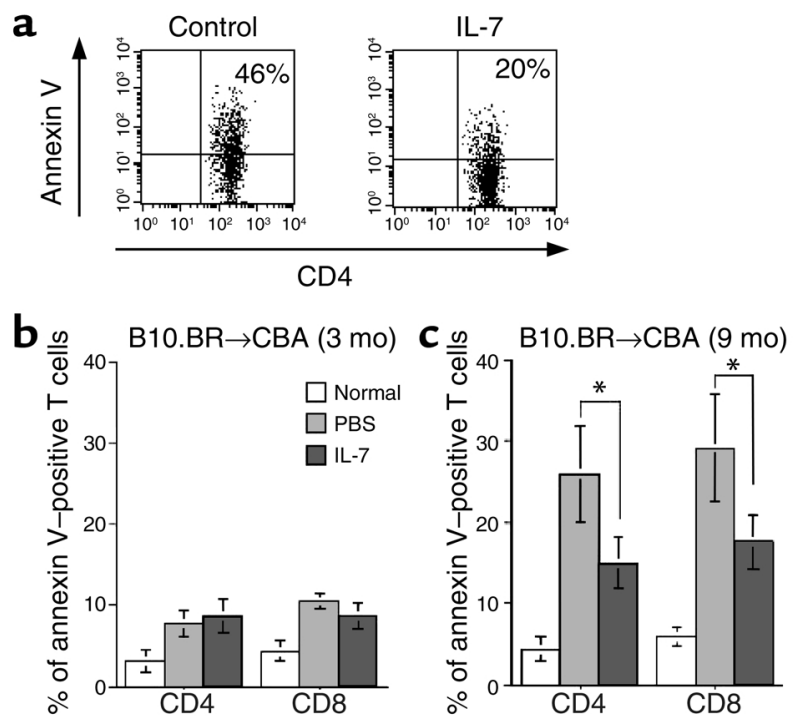

Figure 7

Posttransplant IL-7 administration decreases apoptotic $T$ cells in 9-month-old recipients of allogeneic BMT. (a-c) CBA/J mice (3 months or 9 months old) were transplanted as described in Figure 1 without the addition of T cells. All recipients received $10 \mu \mathrm{g} /$ day IL-7 or PBS (control) by intraperitoneal injection from day 21 to day 27. Animals were sacrificed on day 28, and the percentage of donorderived apoptotic $T$ cells was determined by flow cytometric analysis using annexin $V$ and anti-Ly9.1, -CD4, and -CD8 antibodies. Representative FACS profiles from control and IL-7-treated middle-aged mice are shown in $\mathbf{a}$. The numbers of annexin $\mathrm{V}$-positive donorderived $\mathrm{CD}^{+}$or $\mathrm{CD} 8^{+} \mathrm{T}$ cells from normal B10.BR mice and young and middle-aged allogeneic BMT recipients are shown in $\mathbf{b}$ and $\mathbf{c}$, respectively. Values represent percentage of apoptotic cells from ten animals per group, expressed as mean \pm SEM. $P$ values represent comparisons between IL-7-treated and PBS-treated groups $\left({ }^{*} P<0.05\right)$. 
Our data demonstrate that the expansion of alloreactive and nonalloreactive $T$ cells in allogeneic recipients can be distinguished based upon the number of divisions in the first days after transplant, cell size, and the acquisition of a partially or fully activated cell surface pattern. Interestingly, the early activation marker CD69 is temporarily upregulated on both alloreactive and nonalloreactive T cells before the first cell division has been completed. In our studies, CD25 expression was the most reliable activation marker for differentiation between alloreactive and nonalloreactive donor $\mathrm{T}$ cell populations. We found a greater proliferative and cytokine response in vitro to host antigens by alloreactive (fast-dividing) cells compared with nonalloreactive (slow-dividing) cells, and these results confirm our hypothesis that the fast-dividing population represents alloreactive $T$ cells.

Most studies have indicated that naive $T$ cells require expression of their TCR and contact with the correct restricting $\mathrm{MHC}$ class I or II allele for their survival and/or homeostatic proliferation (40, 56-61). However, some studies have argued that survival and/or homeostatic proliferation of $\mathrm{CD}^{+} \mathrm{T}$ cells can occur without matching MHC class II ligands (62-64). These studies have been questioned because of the possibility of contamination with $\mathrm{MHC}$-expressing antigen-presenting cells among the transferred $\mathrm{CD}^{+}{ }^{+} \mathrm{T}$ cells (19). Seddon and Zamoyska (65) have suggested that TCR and IL-7R signals can drive homeostatic proliferation independently of each other, and we are currently analyzing the requirement for IL-7 and IL-15 in this situation.

We found that posttransplant IL-7 administration in allogeneic HSCT recipients will predominantly result in an expansion of memory-like donor T cells. Apart from its thymopoietic effects $(23,66,67)$, IL-7 has been proposed as an important regulator of lymphoid homeostasis (reviewed in ref. 19). In normal mice, most IL-7 is bound to its receptor on T cells, levels of free IL-7 are low, and $T$ cells have to compete for the limited IL-7 supply. However, in lymphopenic mice, levels of unbound IL-7 increase and naive T cells have increased access to IL-7 and can undergo homeostatic expansion. It is thought that IL-7 potentiates the reactivity of the residual naive $T$ cells against self-ligands, which results in their differentiation into effector $T$ cells and proliferative response. In support of this theory, IL-7 transgenic mice have an expanded memory $T$ cell pool (68). Our data suggest that IL-7 administration to allogeneic BMT recipients, in addition to its thymopoietic effects as previously reported (23), has important extrathymic effects and can stimulate survival and homeostatic proliferation of RTEs and mature T cells in the periphery.

Our findings regarding the importance of homeostatic proliferation for $\mathrm{T}$ cell reconstitution after an allogeneic BMT would suggest that administration of IL-15, which is another important $\gamma_{c}$ cytokine that can regulate $\mathrm{CD}^{+} \mathrm{T}$ cell homeostatic expansion (69), can enhance posttransplant $\mathrm{T}$ cell reconstitution. Indeed, we have found that IL-15 administration increased $\mathrm{CD}^{+} \mathrm{T}$ cell numbers and function after allogeneic BMT and specifically enhanced homeostatic $\mathrm{CD}^{+} \mathrm{T}$ cell proliferation (Ö. Alpdogan, unpublished observations).

When we analyzed CFSE-labeled purified T cells at different timepoints after injection into lethally irradiated recipients, we observed a decrease in IL-7R $\alpha$ expression on donor $\mathrm{T}$ cells transplanted into allogeneic recipients compared with syngeneic recipients. These data suggest that alloreactive $T$ cells undergo rapid downmodulation of IL-7R upon alloactivation. In addition, in a series of mixed lymphocyte reaction (MLR) experiments with splenic $T$ cells from naive animals, or from recipients with GVHD as effectors and irradiated host splenocytes as stimulators, we saw no increase in proliferation with the addition of IL-7 $(0.5-500 \mathrm{ng} / \mathrm{ml})$.

A recent human DNA microarray analysis of T cells incubated with IL-2 demonstrated that IL-7R $\alpha$ was the most potently repressed (four- to fivefold) cytokine receptor (70). This IL-2-induced decrease of IL-7R expression was dependent on PI3K/Akt signaling. Therefore, we hypothesize that the downregulation of IL-7R $\alpha$ on alloreactive $T$ cells may be, at least partially, the result of the autocrine or paracrine effects of IL-2 secretion by these activated $T$ cells. Interestingly, this downregulation of IL-7R $\alpha$ on a population of T cells transferred to an allogeneic recipient occurred before the completion of the first cell cycle, as measured by CFSE expression. In this very early point of T cell infusion, local IL- 2 concentrations are probably very low and difficult to determine. On the other hand, since IL-2 is a potent stimulator of IL-2R $\alpha$, and IL-2R $\alpha$ induction and IL-7R $\alpha$ repression by IL-2 occur concomitantly as demonstrated by Xue et al. (70), the level of IL-2R $\alpha$ expression could be used as an indirect indicator of the presence of IL-2. Only 5.4\% of CFSE-labeled alloreactive $\mathrm{CD}^{+} \mathrm{T}$ cells expressed IL-2R $\alpha$ when analyzed 16 hours after infusion, and the expression of IL-2R $\alpha$ on alloreactive T cells gradually increased over the course of several days. As shown in Figure 2a, 3 days after transfer of CFSE-labeled donor T cells, all fastproliferative $\mathrm{T}$ cells expressed IL-2R $\alpha$ on their surface, whereas homeostatically, slow-proliferating $\mathrm{CD}^{+} \mathrm{T}$ cells did not express IL-2R $\alpha$ on their surface at any timepoint (16 hours, 40 hours, 64 hours, 88 hours, and day 7). Taken together, these data suggest that other factors in addition to IL- 2 can contribute to the downregulation of IL-7R $\alpha$ on alloreactive T cells, especially in the early phase after activation against alloantigens.

In addition, a study using the P14 transgenic mouse to analyze the changes in gene expression (by DNA microarray) during the differentiation of naive antigen-specific $\mathrm{CD}^{+} \mathrm{T}$ cells into effector and memory $\mathrm{T}$ cells demonstrated that IL-7R $\alpha$ expression was diminished (2.4-fold) during the transition from naive to effector T cells (71). Finally, in a recent review by Schluns and Lefrancois (72) regarding $\mathrm{CD}^{+}$memory $\mathrm{T}$ cells, it is suggested that IL-7R expression is downregulated on antigen-specific effector cells, but memory T cells will re-express IL-7R $\alpha$ after antigen clearance and contraction of effector cells.

Important differences between our GVHD experiments and those by Sinha et al. (45), which demonstrated 
increased GVHD at some donor T cell doses, are the use of a different IL-7 preparation at a higher dose and for a longer period of treatment. We had previously observed that even BMT recipients generate neutralizing antibodies against recombinant human IL-7, which has only $81 \%$ homology with murine IL-7 (23). Therefore, in our experiments, recipients were never treated for more than 14 days (either from day 0 to day 14 or from day 14 to day 28), whereas Sinha et al. treated recipients continuously for 4 weeks. We are currently generating recombinant murine IL-7 to analyze the effects of prolonged administration of IL-7 after transplant in our mouse models.

Older recipients of allogeneic HSCT have been shown to have a five- to tenfold higher number of apoptotic $T$ cells in the periphery than do healthy controls, and this was associated with GVHD, human leukocyte antigen disparity, time after transplant, and the expression of Fas and Bcl-2 $(73,74)$. In our experiments, IL-7 administration was capable of decreasing the number of apoptotic peripheral T cells by $50 \%$. Although Bcl-2 levels were significantly decreased in $\mathrm{T}$ cells of older recipients compared with younger recipients (data not shown), we observed only a small increase in Bcl-2 levels in T cells of older IL-7-treated recipients. Therefore the protective effect of IL-7 administration on peripheral T cells cannot be explained by upregulation of $\mathrm{Bcl}-2$, but could involve other IL-7-induced effects on survival, such as PI3K-dependent increased metabolic activity (75) or induction of the transcription factor lung Kruppel-like factor, which is required for naive T cell survival $(76,77)$.

The important role of homeostatic proliferation in posttransplant $T$ cell reconstitution could also partially explain the differences in $\mathrm{CD}^{+}$versus $\mathrm{CD}^{+} \mathrm{T}$ cell reconstitution. $\mathrm{CD}^{+} \mathrm{T}$ cells survive better and engage faster in homeostatic proliferation than $\mathrm{CD}^{+} \mathrm{T}$ cells $(40,62$, 78). In addition, homeostatic expansion of $\mathrm{CD}^{+} \mathrm{T}$ cells is not limited to secondary lymphoid organs and their antigen-presenting cells (79), and does not require ligands for CCR7 (80), whereas homeostatic expansion of $\mathrm{CD}^{+} \mathrm{T}$ cells is limited to lymphoid organs. This increased potential for $\mathrm{CD}^{+} \mathrm{T}$ cells to undergo homeostatic proliferation could result in a better reconstitution of $\mathrm{CD}^{+} \mathrm{T}$ cells than of CD4 ${ }^{+} \mathrm{T}$ cells after transplant.

In conclusion, this study demonstrates the importance of homeostatic proliferation by both mature $T$ cells in the allograft and de novo-generated donor $\mathrm{T}$ cells for posttransplant $T$ cell reconstitution in recipients of an allogeneic HSCT. IL-7 administration has clinical potential to improve posttransplant immune deficiency, because it can promote posttransplant $T$ cell reconstitution through its antiapoptotic and proliferative effects on thymocytes and nonalloreactive mature $\mathrm{T}$ cells without stimulating alloreactive $\mathrm{T}$ cells.

\section{Acknowledgments}

The authors would like to thank the staff of the Research Animal Resource Center for excellent animal care, and Richard O'Reilly and Eric Pamer for helpful discussions and support throughout the project. We would like to thank Samuel Rice, Kartono Tjoe, Marsinay Smith, and Thomas van Huystee for their technical assistance. This work was supported by NIH grants HL-69929 and HL-72412 (M.R.M. van den Brink) and by a translational research grant from the Leukemia and Lymphoma Society (M.R.M. van den Brink). M.R.M. van den Brink is the recipient of a Damon Runyan Scholar Award of the Cancer Research Fund and a research award from the V scholar program of the $V$ Foundation.

1. Kernan, N.A., et al. 1993. Analysis of 462 transplantations from unrelated donors facilitated by the National Marrow Donor Program. N. Engl. J. Med. 328:593-602.

2. Marks, D.I., et al. 1993. Allogeneic bone marrow transplantation for chronic myeloid leukemia using sibling and volunteer unrelated donors. A comparison of complications in the first 2 years. Ann. Intern. Med. 119:207-214.

3. Small, T.N., et al. 1999. Comparison of immune reconstitution after unrelated and related T-cell-depleted bone marrow transplantation: effect of patient age and donor leukocyte infusions. Blood. 93:467-480.

4. Atkinson, K. 1990. Reconstruction of the haemopoietic and immune systems after marrow transplantation. Bone Marrow Transplant. 5:209-226.

5. Linch, D.C., et al. 1983. T cell regeneration after allogeneic and autologous bone marrow transplantation. Br. J. Haematol. 53:451-458.

6. Parkman, R., and Weinberg, K.I. 1997. Immunological reconstitution following bone marrow transplantation. Immunol. Rev. 157:73-78.

7. Witherspoon, R.P., Lum, L.G., Storb, R., and Thomas, E.D. 1982. In vitro regulation of immunoglobulin synthesis after human marrow transplantation. II. Deficient T and non-T lymphocyte function within 3-4 months of allogeneic, syngeneic, or autologous marrow grafting for hematologic malignancy. Blood. 59:844-850.

8. Rozans, M.K., Smith, B.R., Burakoff, S.J., and Miller, R.A. 1986. Long-lasting deficit of functional $T$ cell precursors in human bone marrow transplant recipients revealed by limiting dilution methods. J. Immunol. 136:4040-4048.

9. Daley, J.P., et al. 1987. Retarded recovery of functional T cell frequencies in T cell-depleted bone marrow transplant recipients. Blood. 70:960-964.

10. Heitger, A., et al. 2002. Defective T-helper cell function after T-cell-depleting therapy affecting naive and memory populations. Blood. 99:4053-4062.

11. Roux, E., et al. 2000. Recovery of immune reactivity after T-cell-depleted bone marrow transplantation depends on thymic activity. Blood. 96:2299-2303.

12. Mackall, C.L., and Gress, R.E. 1997. Pathways of T-cell regeneration in mice and humans: implications for bone marrow transplantation and immunotherapy. Immunol. Rev. 157:61-72.

13. Dulude, G., et al. 1997. Thymic and extrathymic differentiation and expansion of T lymphocytes following bone marrow transplantation in irradiated recipients. Exp. Hematol. 25:992-1004.

14. Mackall, C.L., Granger, L., Sheard, M.A., Cepeda, R., and Gress, R.E. 1993. T-cell regeneration after bone marrow transplantation: differential CD45 isoform expression on thymic-derived versus thymic-independent progeny. Blood. 82:2585-2594.

15. Mackall, C.L., et al. 1996. Thymic-independent T cell regeneration occurs via antigen-driven expansion of peripheral $\mathrm{T}$ cells resulting in a repertoire that is limited in diversity and prone to skewing. J. Immunol. 156:4609-4616.

16. Mackall, C.L., Hakim, F.T., and Gress, R.E. 1997. T-cell regeneration: all repertoires are not created equal. Immunol. Today. 18:245-251.

17. Mackall, C.L., Punt, J.A., Morgan, P., Farr, A.G., and Gress, R.E. 1998. Thymic function in young/old chimeras: substantial thymic $T$ cell regenerative capacity despite irreversible age-associated thymic involution. Eur. J. Immunol. 28:1886-1893.

18. Roux, E., et al. 1996. Analysis of T-cell repopulation after allogeneic bone marrow transplantation: significant differences between recipients of T-cell depleted and unmanipulated grafts. Blood. 87:3984-3992.

19. Jameson, S.C. 2002. Maintaining the norm: T-cell homeostasis. Nat. Rev. Immunol. 2:547-556.

20. Namen, A.E., el al. 1988. B cell precursor growth-promoting activity. Purification and characterization of a growth factor active on lymphocyte precursors. J. Exp. Med. 167:988-1002.

21. Peschon, J.J., et al. 1994. Early lymphocyte expansion is severely impaired in interleukin 7 receptor-deficient mice. J. Exp. Med. 180:1955-1960.

22. von Freeden-Jeffry, U., et al. 1995. Lymphopenia in interleukin (IL)-7 genedeleted mice identifies IL-7 as a nonredundant cytokine. J. Exp. Med. 181:1519-1526.

23. Alpdogan, O., et al. 2001. Administration of interleukin-7 after allogeneic bone marrow transplantation improves immune reconstitution without aggravating graft-versus-host disease. Blood. 98:2256-2265. 
24. Okada, S., et al. 1992. In vivo and in vitro stem cell function of c-kit- and Sca-1-positive murine hematopoietic cells. Blood. 80:3044-3050.

25. Cooke, K.R., et al. 1996. An experimental model of idiopathic pneumonia syndrome after bone marrow transplantation. I. The roles of minor $\mathrm{H}$ antigens and endotoxin. Blood. 88:3230-3239.

26. Ishikawa, H., et al. 1993. Cytotoxic and interferon gamma-producing activities of gamma delta $\mathrm{T}$ cells in the mouse intestinal epithelium are strain dependent. Proc. Natl. Acad. Sci. U. S. A. 90:8204-8208.

27. Lyons, A.B., and Parish, C.R. 1994. Determination of lymphocyte division by flow cytometry. J. Immunol. Methods. 171:131-137.

28. Korngold, B., and Sprent, J. 1978. Lethal graft-versus-host disease after bone marrow transplantation across minor histocompatibility barriers in mice. Prevention by removing mature T cells from marrow. J. Exp. Med. 148: $1687-1698$.

29. van den Brink, M.R., Moore, E., Ferrara, J.L., and Burakoff, S.J. 2000. Graftversus-host-disease-associated thymic damage results in the appearance of T cell clones with anti-host reactivity. Transplantation. 69:446-449.

30. Nademanee, A., et al. 1995. The outcome of matched unrelated donor bone marrow transplantation in patients with hematologic malignancies using molecular typing for donor selection and graft-versus-host disease prophylaxis regimen of cyclosporine, methotrexate, and prednisone. Blood. 86:1228-1234

31. Casper, J., et al. 1995. Unrelated bone marrow donor transplants for children with leukemia or myelodysplasia. Blood. 85:2354-2363.

32. Davies, S.M., et al. 1995. Unrelated donor bone marrow transplantation: influence of HLA A and B incompatibility on outcome. Blood. 86:1636-1642

33. Speiser, D.E., et al. 1996. High resolution HLA matching associated with decreased mortality after unrelated bone marrow transplantation. Blood. 87:4455-4462.

34. McGlave, P.B., et al. 2000. Unrelated donor marrow transplantation for chronic myelogenous leukemia: 9 years' experience of the national marrow donor program. Blood. 95:2219-2225.

35. Ferrara, J.L., and Deeg, H.J. 1991. Graft-versus-host disease. N. Engl. J. Med. 324:667-674.

36. Kondo, M., Weissman, I.L., and Akashi, K. 1997. Identification of clonogenic common lymphoid progenitors in mouse bone marrow. Cell. 91:661-672.

37. Shortman, K., Egerton, M., Spangrude, G.J., and Scollay, R. 1990. The generation and fate of thymocytes. Semin. Immunol. 2:3-12.

38. Kieper, W.C., and Jameson, S.C. 1999. Homeostatic expansion and phenotypic conversion of naive T cells in response to self peptide/MHC ligands. Proc. Natl. Acad. Sci. U. S. A. 96:13306-13311.

39. Goldrath, A.W., and Bevan, M.J. 1999. Low-affinity ligands for the TCR drive proliferation of mature $\mathrm{CD}^{+} \mathrm{T}$ cells in lymphopenic hosts. Immunity. 11:183-190.

40. Ernst, B., Lee, D.S., Chang, J.M., Sprent, J., and Surh, C.D. 1999. The peptide ligands mediating positive selection in the thymus control $\mathrm{T}$ cell survival and homeostatic proliferation in the periphery. Immunity. 11:173-181.

41. Surh, C.D., and Sprent, J. 2000. Homeostatic T cell proliferation. How far can T cells be activated to self-ligands? J. Exp. Med. 192:F9-F14

42. Muranski, P., Chmielowski, B., and Ignatowicz, L. 2000. Mature CD4+ T cells perceive a positively selecting class II MHC/peptide complex in the periphery. J. Immunol. 164:3087-3094.

43. Song, H.K., et al. 1999. Tracking alloreactive cell division in vivo. Transplantation. 68:297-299.

44. Suchin, E.J., et al. 2001. Quantifying the frequency of alloreactive T cells in vivo: new answers to an old question. J. Immunol. 166:973-981.

45. Sinha, M.L., Fry, T.J., Fowler, D.H., Miller, G., and Mackall, C.L. 2002. Interleukin 7 worsens graft-versus-host disease. Blood. 100:2642-2649.

46. Loeffler, J., et al. 2002. Quantification of T-cell receptor excision circle DNA using fluorescence resonance energy transfer and the LightCycler system. J. Immunol. Methods. 271:167-175.

47. Lewin, S.R., et al. 2002. Direct evidence for new T-cell generation by patients after either T- cell-depleted or unmodified allogeneic hematopoietic stem cell transplantations. Blood. 100:2235-2242.

48. Storek, J., et al. 2002. Factors influencing T-lymphopoiesis after allogeneic hematopoietic cell transplantation. Transplantation. 73:1154-1158.

49. Hochberg, E.P., et al. 2001. Quantitation of T-cell neogenesis in vivo after allogeneic bone marrow transplantation in adults. Blood. 98:1116-1121.

50. Martinez, C., et al. 1999. Immune reconstitution following allogeneic peripheral blood progenitor cell transplantation: comparison of recipients of positive $\mathrm{CD} 34^{+}$selected grafts with recipients of unmanipulated grafts. Exp. Hematol. 27:561-568.

51. Le Campion, A., et al. 2002. Naive T cells proliferate strongly in neonatal mice in response to self-peptide/self-MHC complexes. Proc. Natl. Acad. Sci. U. S. A. 99:4538-4543.

52. Goldrath, A.W., Bogatzki, L.Y., and Bevan, M.J. 2000. Naive T cells transiently aquire a memory-like phenotype during homeostasis-driven proliferation. J. Exp. Med. 192:557-564.

53. Ge, Q., Hu, H., Eisen, H.N., and Chen, J. 2002. Different contributions of thymopoiesis and homeostasis-driven proliferation to the reconstitution of naive and memory T cell compartments. Proc. Natl. Acad. Sci. U. S. A. 99:2989-2994.

54. Murali-Krishna, K., and Ahmed, R. 2000. Cutting edge: naive T cells masquerading as memory cells. J. Immunol. 165:1733-1737.

55. Tanchot, C., et al. 2002. Conversion of naive T cells to a memory-like phenotype in lymphopenic hosts is not related to a homeostatic mechanism that fills the peripheral naive T cell pool. J. Immunol. 168:5042-5046.

56. Takeda, S., Rodewald, H.R., Arakawa, H., Bluethmann, H., and Shimizu, T. 1996. MHC class II molecules are not required for survival of newly generated $\mathrm{CD}^{+} \mathrm{T}$ cells, but affect their long-term life span. Immunity. 5:217-228.

57. Rooke, R., Waltzinger, C., Benoist, C., and Mathis, D. 1997. Targeted complementation of MHC class II deficiency by intrathymic delivery of recombinant adenoviruses. Immunity. 7:123-134.

58. Viret, C., Wong, F.S., and Janeway, C.A., Jr. 1999. Designing and maintaining the mature TCR repertoire: the continuum of self-peptide:self-MHC complex recognition. Immunity. 10:559-568

59. Witherden, D., et al. 2000. Tetracycline-controllable selection of CD4 $\left(^{+}\right) \mathrm{T}$ cells: half-life and survival signals in the absence of major histocompatibility complex class II molecules. J. Exp. Med. 191:355-364.

60. Labrecque, N., et al. 2001. How much TCR does a T cell need? Immunity. 15:71-82.

61. Polic, B., Kunkel, D., Scheffold, A., and Rajewsky, K. 2001. How alpha beta T cells deal with induced TCR alpha ablation. Proc. Natl. Acad. Sci. U. S. A 98:8744-8749.

62. Bender, J., Mitchell, T., Kappler, J., and Marrack, P. 1999. CD4+ T cell division in irradiated mice requires peptides distinct from those responsible for thymic selection. J. Exp. Med. 190:367-374.

63. Clarke, S.R., and Rudensky, A.Y. 2000. Survival and homeostatic proliferation of naive peripheral $\mathrm{CD} 4^{+} \mathrm{T}$ cells in the absence of self peptide:MHC complexes. J. Immunol. 165:2458-2464.

64. Dorfman, J.R., Stefanova, I., Yasutomo, K., and Germain, R.N. 2000. CD4 ${ }^{+}$ $\mathrm{T}$ cell survival is not directly linked to self-MHC-induced TCR signaling. Nat. Immunol. 1:329-335.

65. Seddon, B., and Zamoyska, R. 2002. TCR and IL-7 receptor signals can operate independently or synergize to promote lymphopenia-induced expansion of naive T cells. J. Immunol. 169:3752-3759.

66. Okamoto, Y., Douek, D.C., McFarland, R.D., and Koup, R.A. 2002. Effects of exogenous interleukin-7 on human thymus function. Blood. 99:2851-2858.

67. Murray, R., Suda, T., Wrighton, N., Lee, F., and Zlotnik, A. 1989. IL-7 is a growth and maintenance factor for mature and immature thymocyte subsets. Int. Immunol. 1:526-531.

68. Sprent, J., Uittenbogaart, C.H., and Fink, P.J. 2002. A season for midwinter immunology. Nat. Immunol. 3:414-416.

69. Tan, J.T., et al. 2002. Interleukin (IL)-15 and IL-7 jointly regulate homeostatic proliferation of memory phenotype $\mathrm{CD}^{+}$cells but are not required for memory phenotype CD4+ cells. J. Exp. Med. 195:1523-1532.

70. Xue, H.H., et al. 2002. IL-2 negatively regulates IL-7 receptor alpha chain expression in activated T lymphocytes. Proc. Natl. Acad. Sci. U. S. A. 99:13759-13764.

71. Kaech, S.M., Hemby, S., Kersh, E., and Ahmed, R. 2002. Molecular and functional profiling of memory CD8 $\mathrm{T}$ cell differentiation. Cell. 111:837-851.

72. Schluns, K.S., and Lefrancois, L. 2003. Cytokine control of memory T-cell development and survival. Nat. Rev. Immunol. 3:269-279.

73. Hebib, N.C., et al. 1999. Peripheral blood T cells generated after allogeneic bone marrow transplantation: lower levels of bcl-2 protein and enhanced sensitivity to spontaneous and CD95-mediated apoptosis in vitro. Abrogation of the apoptotic phenotype coincides with the recovery of normal naive/primed T-cell profiles. Blood. 94:1803-1813.

74. Lin, M.T., et al. 2000. Increased apoptosis of peripheral blood T cells following allogeneic hematopoietic cell transplantation. Blood. 95:3832-3839.

75. Rathmell, J.C., Farkash, E.A., Gao, W., and Thompson, C.B. 2001. IL-7 enhances the survival and maintains the size of naive T cells. J. Immunol. 167:6869-6876

76. Kuo, C.T., Veselits, M.L., and Leiden, J.M. 1997. LKLF: a transcriptional regulator of single-positive $\mathrm{T}$ cell quiescence and survival. Science. 277:1986-1990

77. Schober, S.L., et al. 1999. Expression of the transcription factor lung Kruppel-like factor is regulated by cytokines and correlates with survival of memory T cells in vitro and in vivo. J. Immunol. 163:3662-3667.

78. Ferreira, C., Barthlott, T., Garcia, S., Zamoyska, R., and Stockinger, B. 2000. Differential survival of naive CD4 and CD8 T cells. J. Immunol. 165:3689-3694

79. Dai, Z., and Lakkis, F.G. 2001. Cutting edge: secondary lymphoid organs are essential for maintaining the CD4, but not CD8, naive T cell pool. J. Immunol. 167:6711-6715

80. Ploix, C., Lo, D., and Carson, M.J. 2001. A ligand for the chemokine receptor CCR7 can influence the homeostatic proliferation of CD4 T cells and progression of autoimmunity. J. Immunol. 167:6724-6730. 